\title{
Technology transfer in the interwar U.S. pharmaceutical sector: the case of $E$. Merck of Darmstadt and Merck \& Co., Rahway New Jersey
}

Article

Accepted Version

Godley, A., Joseph, M. and Hughes, D. L. (2019) Technology transfer in the interwar U.S. pharmaceutical sector: the case of E. Merck of Darmstadt and Merck \& Co., Rahway New Jersey. Enterprise and Society, 20 (3). pp. 613-651. ISSN 1467-2235 doi: https://doi.org/10.1017/eso.2018.97 Available at https://centaur.reading.ac.uk/81625/

It is advisable to refer to the publisher's version if you intend to cite from the work. See Guidance on citing.

To link to this article DOI: http://dx.doi.org/10.1017/eso.2018.97

Publisher: Oxford University Press

All outputs in CentAUR are protected by Intellectual Property Rights law, including copyright law. Copyright and IPR is retained by the creators or other copyright holders. Terms and conditions for use of this material are defined in the End User Agreement. 


\section{CentAUR}

Central Archive at the University of Reading

Reading's research outputs online 


\title{
Technology transfer in the interwar U.S. Pharmaceuticals sector: the case of E. Merck of Darmstadt and Merck \& Co., Rahway NJ.
}

\begin{abstract}
This is a case study of the U.S. pharmaceuticals producer, Merck \& Co. By 1940 this was one of the leading pharmaceutical producers in the United States, and went on to become one of the global industry leaders after the second world war. It was founded in 1891 as the U.S. subsidiary of a much larger German pharmaceuticals company, E. Merck of Darmstadt. The existing understanding of Merck \& Co's history emphasises how it was reacquired by the American branch of the Merck family after wartime sequestration, and that from then onwards it pursued a path of development separate from its former parent. This article revisits that history of the company and shows how the two Merck's began to co operate and share technology and manufacturing knowhow during the 1930s, something which was particularly to the advantage of Merck \& Co.
\end{abstract}

\section{INTRODUCTION}

The recognition in the United States during World War One of its dependence on German manufactured dyestuffs and advanced pharmaceuticals shocked public opinion. The dominance of key markets by enemy producers prompted important policy changes. The sequestration of all German-owned U.S. assets by the Alien Property Custodian followed U.S. entry into the war in 1917. German pharmaceutical factories and patents were sold on to U.S. interests with the explicit aim of stimulating domestic production. Prohibitive tariffs on imported chemicals and pharmaceuticals were introduced after the war, stopping any resumption of the import trade in its tracks and so reducing competitive pressures on the emerging U.S. pharmaceuticals sector. ${ }^{1}$

The indigenous American pharmaceutical industry was dominated by 'patent-medicine' producers, specialist producers of vigorously promoted herbal elixirs and tinctures of doubtful efficacy. The impact on the American pharmaceuticals industry of these policy changes was seemingly profound. German manufactured medicines were no longer competitive in the U.S. market. After a generation of German producers building 'patent thickets' in the U.S. market as a competitive barrier, suddenly U.S. pharmaceuticals producers could gain access to German intellectual property. ${ }^{2}$ There were, however, only a few American ethical pharmaceuticals manufacturers which had sufficient manufacturing capabilities to be able to utilise German technologies. Abbott successfully acquired the valuable Bayer patent for synthesising salicylic acid, the basis of producing aspirin, for example, and subsequently developed a science-focused business in the 1920s and 1930s. ${ }^{3}$ But most American producers struggled to adapt. U.S. pharmaceuticals output increased by only just over one third from 1922 to 1928, nearly half of this in salicylic acid production alone. Given that the dominant suppliers to the U.S. market had been forcibly removed by government decree on entry into the war, this does not seem a particularly fast rate of growth. ${ }^{4}$ 
Just over a decade later, however, by the time of the U.S. entry into World War Two, the biggest American pharmaceutical companies - Abbott, Lilly, Merck, Parke, Davis and Pfizer - had all acquired sufficient technological capabilities that they were able to make major contributions to the war effort, through the crash penicillin program, plasma production, sulfas and other important therapies. They were therefore well positioned to benefit after the war and enjoyed around half the global market in the early 1950 s. $^{5}$ While the forced removal of German competition created the opportunity for the indigenous U.S. industry to develop in the 1920s, it was in fact in the 1930s that a dramatic transformation in the technological and manufacturing capabilities of the U.S. pharmaceuticals industry occurred. ${ }^{6}$

The consensus among historians of the American pharmaceutical industry is that this transition occurred because of a combination of a much greater commitment to internal research among American firms and the growth of increasingly strong collaborative networks between the leading university chemists and private companies. ${ }^{7}$ The fragmentary data that exist for individual firms also suggests that research intensity among the leading firms increased during the 1930s.

Abbott spent around $\$ 100,000$ annually on research in the early to mid-1930s (and had a research staff of 29 by 1933), probably representing a research intensity of around $2 \frac{1}{2}$ percent of sales during the mid 1930s. ${ }^{8}$ Lilly's expenditure on R\&D was claimed to be between two and three percent of sales in $1930 .{ }^{9}$ Merck \& Co's research intensity grew from only 0.3 percent of sales in 1929 and 0.5 percent in 1930 , to 1.4 percent in 1931, and 1.5 percent in 1932, 2.0 percent in 1933, 2.3 percent in 1934, 2.4 percent in 1935, 2.8 percent in 1936, 3.2 percent in 1938, 3.3 percent in 1939, and then to 3.9 percent in $1940 .{ }^{10}$ There are less data for other firms. What do exist seem to indicate that research intensity was lower elsewhere. ${ }^{11}$

Table 1 shows that the leading American ethical pharmaceutical companies also saw a substantial increase in patenting activities in the 1930s. Before World War One American pharmaceutical companies had conducted very little patenting. But the Table indicates that by 1932 Abbott and Lilly were making some efforts to patent pharmaceutical innovations. Until 1936 Abbott and Lilly were behaving somewhat differently to Merck and Parke, Davis. But from 1938 Merck began to patent at a level which exceeded all the others. The evidence of increasing research expenditures and patenting levels among these leading American pharmaceutical companies appear to support the view that these firms experienced a transition during the 1930s and became research-focused organisations, developing internal research capabilities and strong links to leading scientists at U.S. universities.

$<$ Table 1 about here $>$

This article is a case study of Merck \& Co, a firm clearly identified by both contemporaries and subsequently by historians as one of the industry leaders during the 1930 s. $^{12}$ As the research expenditure and patenting data suggest, by 1940 Merck \& Co was seemingly the most research intensive American pharmaceutical producer. This article aims to show that Merck \& Co's rise to industry leadership followed a somewhat 
different path to its peers in the 1930s, depending on a largely concealed transfer of technology and know-how during the 1930s from its former German parent, E. Merck of Darmstadt. This aspect of Merck \& Co's history has been omitted from the official corporate histories and largely ignored by academic studies. Transfers of German technology and know-how to American firms were not unknown during the interwar period. Steen describes several such relationships among synthetic dyestuffs producers, for instance. ${ }^{13}$ Within the smaller pharmaceuticals niche, Bayer had formed the Winthrop Group with Sterling in order to reacquire its U.S. patents and markets in the early1920s, and Schering re-established its U.S. subsidiary in $1933 .{ }^{14}$ But, this article contends that these were relatively insignificant. Neither of the U.S. operations of Winthrop/Sterling or Schering acquired sufficient prominence in research to be included in the U.S. war effort, for example, in contrast to Merck \& Co. ${ }^{15}$

The article makes three contributions to the business history literature on the development of the U.S. pharmaceuticals industry in the 1930s. First, it offers a substantially more detailed account of the extensive scientific and commercial interrelationships of the two Mercks between 1919 and 1940 than is currently available. Second, the article shows that E. Merck's research and scientific capabilities remained significantly ahead of Merck \& Co, until at least 1938. Third, the case of Merck \& Co shows that where this leading U.S. pharmaceutical producer did gain a clear advantage over its former German parent in the late 1930s was in pharmaceutical manufacturing. Given Merck \& Co's prominence in the industry in the late 1930s and 1940 s, we speculate that this may suggest that advances in understanding process technologies may have been a more significant source of the U.S. industry's remarkable success in producing new medicines during World War Two than is currently recognised. ${ }^{16}$

The article is organised as follows. The next section describes the two Mercks' relative positions in 1914, the date from which the U.S. subsidiary effectively became an autonomous unit. The impact of the U.S. entry into the war in 1917 on Merck \& Co and its forced separation from Darmstadt is then outlined. Without access to its former parent's products, Merck \& Co. struggled in the 1920s, precipitating a merger with another former German-U.S. fine chemical producer, Powers Waters Rosengarten in 1927. The existing business history literature on Merck \& Co emphasizes the complete separation of the two Mercks by this point. But here we show how, in fact, this merger became the catalyst for the intensification of the commercial relationship between the two Mercks, leading to the signing of a treaty in 1932 that promulgated a very substantial transfer of product and process technologies from Germany to the U.S. in the 1930s. The implications of this case study are discussed in the concluding section.

\section{E. MERCK OF DARMSTADT AND THE GROWTH OF MERCK AND CO TO 1914}

While the large German dyestuffs producers (BASF, Bayer and Hoechst) had already successfully diversified into pharmaceuticals production, by 1914 the venerable E. Merck of Darmstadt was Germany's largest producer of pharmaceuticals. ${ }^{17}$ Merck \& Co was the outcome of E. Merck's decision in 1891 to upgrade its New York agency into a wholly-owned distributor. E. Merck was founded by Emmanuel Merck (1794-1855) as a 
manufacturer and distributor of fine chemicals to pharmacists. Emmanuel's sons - Carl, Georg and Wilhelm - expanded it. Wilhelm was a trained scientist. His elder son, Carl Emmanuel, followed in the family's scientific tradition, becoming steeped in the chemistry of alkaloids. George F. Merck was Wilhelm's second son, and was trained in commerce, with a brief to expand the firm's overseas' business. ${ }^{18}$ Wilhelm posted George to London and Paris to learn about the leading foreign markets, before he arrived in New York in 1891 to oversee the newly created subsidiary. ${ }^{19}$

Merck \& Co quickly became an important supplier of E. Merck's products to the U.S. market. It grew quickly, employing 180 people by 1896, somewhat smaller than the leading U.S. wholesaler, SmithKline, which employed 265 in 1895. ${ }^{20}$ In 1902 SmithKline's sales reached $\$ 3 \mathrm{~m}$ and it marketed 15,000 different product lines. ${ }^{21}$ Merck \& Co’s 1902 sales were just over \$1.5m. By 1914 it marketed 3,500 to 4,000 items in the U.S. But these represented only a third of the total number of products E. Merck had available in Germany. The U.S. subsidiary was relocated to Rahway, NJ, where it shortly began to manufacture around 1,000 of the more basic items by 1914, by which point its sales exceeded $\$ 3 \mathrm{~m}$. Merck \& Co had grown to attain some significance since 1891 but it remained 'organizationally, technically and financially... tightly linked to the German parent'.22

German success is typically explained by a combination of the creation of a specific model for industrial research, pursued at a scale hitherto unknown. ${ }^{23}$ Large German pharmaceuticals firms were typically ten times bigger than their U.S. peers, and so able to finance far more ambitious and so successful research programmes. ${ }^{24}$ In $1890 \mathrm{E}$. Merck's key products were processed alkaloids (cocaine, morphine, etc), some semisynthesized galenicals (such as salycilic acid) and an enormous range of reagents, intermediate products and industrial chemicals. ${ }^{25}$ It pursued an ambitious research programme, depending on its collaborations with several of Germany's leading scientists in its universities and, from 1911 onwards, the newly formed Kaiser Wilhelm Institutes. ${ }^{26} \mathrm{E}$. Merck's increasing research intensity saw its research expenditure rise from just under 2.5 percent of sales between 1902 to 1905 to perhaps over 3 percent of sales by $1912 .{ }^{27}$ Burhop's analysis of E. Merck's profitability shows that by 1913 and 1918 the company was dependent on ten products for the overwhelming majority of its pharmaceuticals sales and profits, all of which were invented between 1890 and 1905 (the leading six sellers in 1918 were all invented in just eight years from 1895 to 1903). ${ }^{28}$ These blockbusters powered its global growth in the years before 1914, including in the United States. ${ }^{29}$ Veronal, for example, (invented in 1903) became the leading barbiturate sedative in the United States. ${ }^{30}$

From late 1914 the British blockade on raw drug imports prompted German producers to innovate, with new products emerging to replace now unobtainable raw drugs. ${ }^{31}$ The absence of raw drugs in Germany also influenced pharmacists' practice, as it 'accelerated the pace at which pharmaceutical specialties were replacing raw materials', which therefore gave the leading research-intensive producers more incentive to develop their own brands. ${ }^{32}$

E. Merck augmented its position as one of the leading German firms in the interwar period, moving into packaging its medicines in tablet form. E. Merck employee numbers increased to 3,600 by 1923 before stabilizing at around 3,000 between 1924 and 1932, 
then increasing to 4,100 by 1938.33 The company increased its investment in in-house research, establishing a central laboratory in 1927, and was successful in developing new products. ${ }^{34}$ It led to major innovations in plant-protection agents, synthetic vitamins $\mathrm{A}, \mathrm{C}$ and $\mathrm{D}$, hormone products, as well as further developments in sedatives and anesthetics. ${ }^{35}$ By 1939 E. Merck together with other leading producers had increased Germany's share of world exports in pharmaceuticals from 30 percent (in 1913) to 43 percent. ${ }^{36}$

The German parent was therefore very much the dominant partner in the early years of Merck \& Co's existence. It was a straightforward parent-subsidiary relationship, like many German immigrant businesses in the U.S. before 1917. The Darmstadt company was much bigger than the Rahway subsidiary (see Table 2) and remained so through until 1940. Despite the losses from World War One, E. Merck continued as one of the world's leading, research-intensive pharmaceutical producers throughout the interwar period.

$<$ Table 2 about here $>$

\section{MERCK \& CO.: WORLD WAR ONE SEQUESTRATION AND CONDITIONAL REACQUISITION}

The U.S. Government's Alien Property Custodian (APC) sequestrated all German-owned U.S. assets on entering World War One in 1917, including, in April 1918, E. Merck's 80 percent shareholding in Merck \& Co. Despite being a U.S. citizen, George F. Merck was also compelled to turn over two thirds of his personal 20 percent stake in Merck \& Co to the APC in return for the concession that he could continue as its President. ${ }^{37}$ The Alien Property Custodian then sold off as many of these sequestered asset as possible to American companies and American citizens. ${ }^{38}$ Despite being a U.S. citizen and long-time resident, given his German background and continued family links to the original German parent, George F. Merck was viewed with suspicion. ${ }^{39}$ So when George F emerged victorious at the auction in May 1919 and reacquired control of the company, there was some considerable official consternation with the German connection. ${ }^{40}$ W.H. Moran, Chief of the Secret Service, commissioned a report to investigate the sale. But the strongest words came from Francis P. Garvan (the Alien Property Custodian) writing to the Advisory Sales Committee of the Aliens Property Custodian, expressing strong reservations at the outcome.

Garvan's priority was to safeguard 'the importance to the American people of the clean, unGermanized manufacture and sale of drugs'. But George F. Merck had now reacquired control of Merck \& Co., where 'the temptation which must exist to those of former German inclination [i.e. George F. Merck] to take advantage of the increased return from a combination with E. Merck' would be so overwhelming, because the 'financial advantage [to Merck \& Co] of a re-alliance with E. Merck of Darmstadt would be tremendous'. Furthermore, George F. Merck could not be trusted to keep to any promise to refrain from any connection with Darmstadt, because 'his [George F. Merck's] business practices are of the usual secretive German practices'. This conundrum meant that the 'close connection between Merck \& Co and E. Merck of Darmstadt, requires 
unusual supervision and watchfulness against the renewal of this affiliation after the bars are let down for the resumption of trade between this country and Germany'. ${ }^{41}$

The result was that as a condition of the sale, George F. Merck was forced to agree to a Trust that oversaw his management of Merck \& Co for ten years from July 23rd, 1919. The Trust's 'purpose [is] ... to insure the continuous Americanization of the business of Merck \& Co, both in operation and control... to ensure during the term of the Trust no stock be sold to German citizens, German corporations or corporations mainly controlled by German citizens.... The close connection between Merck \& Co and E. Merck of Darmstadt, requires unusual supervision and watchfulness against a renewal of this affiliation'. And while the Trust provided for early termination under limited circumstances, this was conditional on 'such termination will not thwart such purposes'. Direction of the firm remained with George F. Merck. But crucially the trustees were empowered 'to ensure the continuous Americanization of the business...' 42 Merck \& Co was therefore forced from July 1919 to sever all ties with Darmstadt.

In the official corporate history of Merck \& Co, Galambos and Sturchio present this transfer of ownership as the fundamental break with Darmstadt. ${ }^{43}$ This view was reinforced with a more detailed discussion of the transfer of ownership and subsequent developments to 1925 in a 1994 publication. ${ }^{44}$ Here the authors emphasized that while the legal break up and the formation of the Trust in 1919 led to a complete and irrevocable separation, there remained some ongoing business ties in the early 1920s. As 'soon as the bid was officially accepted by the government, the legal break between E. Merck and Merck \& Company was completed. The American company was on its own.' The terms of the Trust were to ensure the 'continuous Americanization of the business' had to be followed. ${ }^{45}$

At times Merck \& Co still drew upon E. Merck for technological assistance, and it became again a distributor for the Darmstadt company's products. But now the U.S. firm was increasingly able to look to domestic sources of scientific and technological information and expertise as it moved into new products and new technologies.... By [1925] this American offspring of E. Merck was financially and managerially autonomous, a multinational in its own right, and a business that would play an important role in the merger movement that would sweep through the American chemical industry...46

This was certainly how the firm later presented its interwar experiences. In 1942 George Perkins wrote to Foreign Funds Control Division of the Federal Reserve Bank of New York in order to explore whether Merck \& Co. might be a possible bidder for the recently sequestrated U.S. subsidiary of Schering. After rehearsing the outcome of the 1919 reacquisition of Merck \& Co. by George F. Merck from the Alien Property Custodian, Perkins underlined the full and complete separation of Merck \& Co. from E. Merck of Darmstadt, emphasizing that Merck \& Co. had fully complied with the terms of the Trust. While there had been some necessary interchange between the German and American Mercks in the 1920s to resolve the rights to the Merck name, Perkins was vehement, emphasizing that there had never been any mutual 'ownership interest,... influence or control, directly or indirectly' between the two companies since 1919.47 
In a later 2011 publication the same authors reviewed the relationship between the two Mercks, and offered an important nuance to their original view, that the APC-mandated separation was the sole critical event. In this later article the authors outlined how George F Merck, despite now being in control of the independent American Merck, actually would have preferred to have reverted to the pre-war business model.

German blood was thicker than the strict rules of coporate governance... the flow of ideas from Darmstadt continued on an informal basis until George [F] Merck's death in 1926.

It was only when George F.'s son, George W. Merck, became president in 1925 that,

the company appears to have adopted a new business strategy. The links to Germany and E. Merck appear at last to have been broken, and a thoroughly American corporation emerged. Through acquisition and through a new approach to research and development, the new president of the business internalised functions that had for forty years been provided by E. Merck. ${ }^{48}$

In this later piece the authors suggest that the change in leadership of 1925 led to the decisive break with Darmstadt, as opposed to the formal transfer of ownership of 1919. They go on to state that George W.'s strategy was to replicate the Darmstadt business model in the U.S. ${ }^{49}$

But the basic business strategy of getting close to advanced medical science, developing internal capabilities as well as elaborate external networks, and stressing the purity of their products and the scientific nature of the processes were all familiar well-tested E. Merck strategies. ${ }^{50}$

This need to internalise the previously Darmstadt-based research function then explains the investment in new research laboratories in the early 1930s, and notably the Merck Institute of Therapeutic Research. ${ }^{51}$ The authors emphasize that the ability of George W. Merck to replicate the Darmstadt business model at Rahway was based around shared values, leadership and culture.

German business practices, culture, and history helped lay the foundation for America's climb to leadership in world pharmaceuticals after World War II and for Merck \& Co. Inc.'s achievements in those decades ${ }^{52}$

The most detailed summaries of the World War One sequestration and reacquisition of Merck \& Co by the Merck family are therefore clear that the 1919 formal separation of the two companies was henceforth irrevocable, and that the continuation of ties between the two Merck companies was restricted to a relatively small number of activities. While George F. Merck may have preferred to have returned to the pre-war relationship, under the terms of the Trust this was impossible. His son, George W. Merck grasped the nettle of independence on taking formal control of Merck \& Co and sought to replicate the Darmstadt model, internalizing the higher value activities such as research at Rahway that had previously only been located at Darmstadt. Other scholarly work on Merck \& Co's interwar evolution corroborate this view, that George W. Merck successfully built a fully independent American equivalent of E. Merck of Darmstadt. ${ }^{53}$ 
Much of this understanding of Merck \& Co's evolution is based on research on correspondence between the two companies during the 1920s which was held held at Merck \& Co's archives. The different interpretation presented here is based on hitherto unused materials held at the archive of E. Merck at Darmstadt. ${ }^{54}$ This new data suggest that Merck's 1919 separation from E. Merck was far from irrevocable and that George W. Merck's strategy after assuming the Presidency was not to pursue total autonomy from Darmstadt.

\section{BREAKING THE TRUST.}

Constrained by the terms of the Trust, George F. Merck was faced with a stark choice after World War One. He could have continued to specialize in fine chemicals production, but, after the wartime boom, conditions in fine chemicals were increasingly difficult (see Figure 2 below). He could have copied other ethical pharmaceuticals companies, such as Squibb, Sterling, Sharp and Dohme and others, that were diversifying into consumer goods. Or he could have ignored the terms of the Trust and reassert the pre-war business model. It was this latter option that he chose.

On September $12^{\text {th }}, 1919$, less than two months after the formal agreement of the Trust, and in complete contradiction of its terms, George F. Merck cabled E. Merck, saying, 'We are now authorized to trade with you and will be glad to receive quotations. Our George W Merck will call on you next month'. ${ }^{55}$ George F. and George W. Merck were eager to resume ties immediately. But the German cousins, Karl and Louis Merck in Darmstadt, were more circumspect and more concerned with clarifying exactly what U.S. assets E. Merck could lay claim to. The American Mercks were trying to recreate the pre-war business relationship as quickly as possible. In December 1920 George W. Merck exclaimed, the 'physical obstacle of the Atlantic is but a small matter when the basis of our understanding is so firmly established. You need never concern yourself that any small untoward incident will influence the true course of our relations. ${ }^{56}$

But war-time restrictions on trade were only slowly repealed. Then in 1921 and 1922 tariffs on most pharmaceutical imports were doubled or more. This posed a significant threat to any resumption of the two Merck companies' pre-war business relationship. After having been dominated by German imports up to 1914, the U.S. pharmaceutical market suddenly became supplied almost entirely by domestically produced output. Only 1.8 percent of U.S. consumption of pharmaceutical products was imported in the late 1920 s. $^{57}$

It was only with the final settlement of the peace treaties in August 1921 that there was a legal structure in place in the U.S to address the outstanding legal claims from German citizens. ${ }^{58}$ In late 1921 Karl Merck visited Rahway to discuss Darmstadt's loss of its former U.S. subsidiary. There were two issues that needed to be resolved. First, to review the terms and conditions of the compensation E. Merck was to receive from the U.S. government arising from the sequestration and then sale of the German-owned assets of Merck \& Co. Second, to clarify the rights to the name 'Merck' that the newly independent Merck \& Co might own in the U.S. and other markets. 
The financial settlement was complicated by the opacity of cross-ownership ties between the Darmstadt and Rahway branches of the Merck family. While all agreed that Darmstadt owned 80 percent of the U.S. subsidiary and George F. Merck the balance of 20 percent, George F. Merck had also claimed to the Alien Property Custodian that he had lost his 19 percent share of ownership in the Darmstadt parent without compensation. The U.S. authorities accepted his valuation of this stake as $\$ 1,020,108$, and so reimbursed him from the proceeds of the $\$ 3.75$ million raised from the sale of Darmstadt's 80 percent stake of Merck \& Co. ${ }^{59}$ It was this sum that Karl Merck wanted to review during late 1921 . The cousins arrived at some satisfactory but unwritten solution, where George F. Merck voluntarily returned to Darmstadt $\$ 400,000$ in recognition that he had been overpaid for his interest in E. Merck. From this point on 'extremely cordial' relations between the two Merck's resumed, albeit always on the basis of 'informal cooperation'.60 Indeed, given the closeness of the ties between the two Mercks from 1921, the number of formal agreements was remarkably small. 'Research information was exchanged, the executives of the two companies often visited each other, business information was given to each other,' Merck \& Co. resumed their prewar role as the U.S. distributor for E. Merck, and a market share agreement, determining which company was allowed to sell in which market, was strictly observed. But all this was based on verbal agreements. The only written agreements were a handful of licensing agreements. ${ }^{61}$

Once the financial consequences of the sequestration had been resolved, the correspondence between the two companies reflected the fluctuations in the new business relationship. During the early 1920s, as Galambos and Sturchio state, the two companies had cordial, but increasingly distant relations. What will become clear, however, is that this fundamentally changed from the end of the 1920s onwards.

\section{DWINDLING AFFECTIONS: THE 1920s}

The first contact after the financial resolution of the two companies' severance came when George W. Merck wrote to Karl Merck on January 30th 1922. George W. reported that progress was being made in selling Darmstadt's specialties, albeit deliberately gradual, so as to avoid the 'danger of raising a cry of "German specialties deluging the market,"' but marketing efforts were nevertheless being increased. While this was a welcome outcome from Karl's visit of late 1921, it was the 'interchange of information [on manufacturing processes that] is most profitable' to Rahway. ${ }^{62}$ George W. hoped that some of Rahway's processes might be of reciprocal interest to Darmstadt. But Karl replied that none of the manufacturing processes Rahway had suggested Darmstadt might want to adopt were worthwhile. 63

The increases in tariff barriers in 1921 and 1922 made importing increasingly costineffective. George W. wrote again in early April asking whether the former Rahway factory manager might come and spend some days at Darmstadt, and, through detailed conversations with Fritz Merck, learn how to apply the superior Darmstadt processes in Rahway. ${ }^{64}$ George W. was trying to persuade Darmstadt to let Rahway manufacture more of their specialties rather than simply distribute increasingly costly imported goods. 
The Rahway factory manager was welcomed with open arms by Darmstadt and given as much information as needed about how to change Rahway's processes and make them more profitable. ${ }^{65}$ George W. pursued this theme in July 1922, emphasizing that tariffs now made it prohibitively expensive to import even the newest specialty (called 'Eukodal'), so could Darmstadt please provide the necessary information and materials to support its manufacture at Rahway. He reinforced this with a request for permission to manufacture another product, Skiabaryt, in December 1922.66 Karl's reply did not directly address this request but instead proposed a visit was needed for further discussion. ${ }^{67}$ But that visit did not take place. After the initial surge in enthusiasm for the rekindling of commercial relations between the two Mercks, Darmstadt began to lose interest. Two years later in November 1924, George W. Merck insisted to Louis Merck that it 'would be of inordinate value to the business to have you with us again for a while... it has been a long time since someone from Darmstadt has been here,' and that Merck \& Co were eager to 'develop the business with your products in our territory', especially with specialties. Louis' reply to George W. exposed the fragility of the unwritten 'agreement' between the cousins. For while Darmstadt was happy for a few of their products to be manufactured in Rahway, this was on the basis that Merck \& Co would be an effective distributor for Darmstadt manufactured goods in the U.S. But the U.S. sales of Darmstadt's products since the end of the war had proven to be very disappointing. Total sales of all E. Merck goods in the U.S. during 1922 to 1924 were only one-third their (nominal) 1913 value. The sales performance of Darmstadt manufactured specialties was even worse. This criticism must have stung. It exposed Merck \& Co.'s dependence on E. Merck's products. George W.'s response was to insist that the adverse impact of increased tariff barriers as well as the wartime loss of patent protection - 'through no fault of ours' - meant that the true 'picture is a different one'. Darmstadt weren't interested. ${ }^{68}$

Plans for Louis' visit to New York were cancelled. Silence reigned. In the summer of 1925 George was reduced to rather petulantly complaining about possible sales territory incursions. ${ }^{69}$ In October 1925 George W. tried again, now in his position as President of Merck \& Co, after George F.'s retirement. He implored someone to visit. 'Except for Karl's visit [in 1921], which really had to do with financial matters, we have had no one from your House since before the War. But sooner or later, and probably later, there will be a revision of the tariff downward', he added. If there was little prospect of any meaningful return to Rahway's role as Darmstadt's distributor, then surely Darmstadt could show Rahway how to manufacture their specialties, 'which at present I see as our greatest hope. I think we could learn a great deal from you. Rudi Gruber is trying to arrange to get abroad early next year to spend some weeks with you, particularly your Specialties Department.'70

There was still no response. In the immediate aftermath of resolving the postwar financial settlement and market-sharing agreement, Darmstadt had given manufacturing licenses and supplied complete information on their production to Merck \& Co. for six specialties. In return they expected Merck \& Co to promote Darmstadt manufactured specialties. After 1925, apart from one mutual exchange of information, there were no subsequent agreements before $1932 .{ }^{71}$ Given the sense of optimism in 1922, the stalling of any progress in returning to the pre-war business relationship must have been disappointing for the two George Mercks. 
The reconstituted Merck \& Co had found conditions difficult in the 1920s. Revenues slumped from $\$ 8.15 \mathrm{~m}$ in 1917 to only $\$ 4.36 \mathrm{~m}$ in 1921 . Employment levels were cut by a third shortly after Armistice. Sales only slowly rose to $\$ 6.4 \mathrm{~m}$ by 1926 . In real terms, revenues had fallen by half over the decade (see Figure 2). ${ }^{72}$ As the new president, George W. Merck's first major decision to arrest this decline was to acquire the larger specialty chemicals manufacturer, Powers Weightman Rosengarten, in 1927. According to Adolphe Rosengarten, Merck \& Co. were 'in trouble'. The financing of the reacquisition of Merck and Co. by George F. Merck in 1919 had been undertaken by issuing preference shares, and by 1927 Merck \& Co was falling behind on its repayments. ${ }^{73}$ The merger enabled Merck immediately to acquire some increased significance in the fine chemicals market. Sales rose to $\$ 13.1 \mathrm{~m}$ in 1928 , but then fell again to $\$ 9.21 \mathrm{~m}$ in 1932 and remained stagnant during the worst of the Depression. Costs were cut and manufacturing capacity was rationalized onto the Rahway site. ${ }^{74}$

$<$ Figure 2 about here $>$

The merger meant that the newly constituted Merck \& Co Inc. was the largest fine chemical manufacturer in the U.S. As noted above, it has been interpreted by Merck \& Co's historians as a statement of George W. Merck's pursuit of an independent business strategy. ${ }^{75}$ One consequence of the merger with PWR was that the Trust was formally ended. Of course, from the outset the two George Mercks had set about to thwart Garvan's intention to ensure a permanent severance of ties between Darmstadt and Rahway with the Trust. Ironically, however, Darmstadt's calculation of its interests in the United States was leading ineluctably to Garvan's goal because of Darmstadt's commitment to a home-base-manufacture-and-export model, and Rahway's inability to promote German imported products to the U.S. market sufficiently well to overcome the prices imposed by the tariff barriers. The merger was the clearest statement by George W. Merck that the strategy of recreating the pre-war relationship had failed, not because of the Trust, but because of Darmstadt's unwillingness to deviate from their strategy of centralized manufacturing, and so their unwillingness to support Rahway's desire to increase the range of products (in particular pharmaceutical specialties) it was also able to manufacture. Without access to Darmstadt technologies and know-how, Merck \& Co might try and recreate the Darmstadt model at Rahway through their own efforts, but that was an extremely difficult business strategy to pull off. But, in what can only be seen as a remarkable change of fortunes, the merger precipitated a change of heart at Darmstadt towards Rahway.

THE 'TREATY AGREEMENT', NOVEMBER 17TH 1932, AND THE 'PROTOCOL' NOVEMBER 1934

The merger with PWR made Merck \& Co a much more significant operation, perhaps around half the size of E. Merck. After the merger, 'a definite change came in E. Merck's attitude to Merck \& Co.'76 Within a few months George W. Merck and Fritz Rosengarten had visited Darmstadt. After several years of increasingly frosty relations, George W. was delighted. In a long letter to Karl Merck, he enthused about the renewal of the close relationship between our two houses [in which] lies a source of great strength - something from which our ever closer entente can be brought about. 
Perhaps it is not outside the scope of probability that we may live to see the conditions as they should have been before the War established - perhaps even in more extensive form...

Darmstadt insisted on their conditions being met, however.

Of course I have kept daily before me the matters we discussed together in Darmstadt, and in particular various points of contact which must be satisfactorily conducted in order that a relationship of real mutual benefit may be brought about.77

George W. went on to detail responses to the longstanding Darmstadt concerns that Merck \& Co were not promoting their German manufactured chemicals and specialties sufficiently, and ensuring that the newly merged Merck and PWR would not encroach on E. Merck overseas markets. ${ }^{78}$

George W. emphasized again the impact of tariffs on German imported goods, and while he reiterated that there might be U.S. demand for German made specialties, he returned to what had been a recurrent, but rebuffed, theme since 1922.

Generally speaking, the best opportunities for developing manufacture over here are not in staple products, but in specialties - either in patented medicinal specialties or special articles for certain industries. ${ }^{79}$

After years of Darmstadt showing little interest in changing their business to accommodate Rahway, the PWR merger had prompted a visit, which now changed their response. Correspondence grew as business relations intensified through 1929 and 1930.80

In October 1930 Karl paid an extended visit to Rahway. This was the precursor to what was a significant international agreement between the two Merck companies. After the passage of the Smoot-Hawley Tariff Act in the summer of 1930, it was evident that tariffs were not going to be reduced. In order for E. Merck to regain their share of the U.S. market they would have to open a manufacturing subsidiary there. Since the passage of the Settlement of War Claims Act, the way was open for German firms once again to establish U.S. subsidiaries. ${ }^{81}$ But Darmstadt's relationship with Rahway meant that increasing its U.S. market share might be more easily met through agreeing to what had been Rahway's preferred strategy since 1919, of licensing the manufacturing of E. Merck products to them. Darmstadt had resisted any substantial development of this model. Their strong preference was for centralizing production of pharmaceuticals at Darmstadt and then exporting around the world. This was perfectly understandable given how important quality control was to pharmaceutical production. ${ }^{82}$ Allowing Rahway to manufacture under license introduced the risk of lower manufacturing standards. But the seeming permanence of imports being shut out of the U.S. market meant that the bullet of local manufacturing had to be bitten.

Certainly both parties had a strong incentive to reinvigorate the relationship. But Darmstadt wanted it formalized. After another extended visit to Rahway, in November 1931 Karl Merck gave Louis Merck an update on the discussions on what led to what became known as the 'Treaty Agreement'. The German objective was three-fold: to get a 
formal agreement about which company could export to which overseas market; to have a clear idea about and accounting for the profit-sharing on the Darmstadt manufacturing processes that Rahway were always so eager to adopt; and to limit Rahway's access to Darmstadt technology. ${ }^{83}$ It took a further year before the Treaty was signed. George W. Merck could only offer a 'practical working understanding' with respect to the proposed restrictions on export markets, something which was later seized on by U.S. anti-trust investigators. ${ }^{84}$ Karl and Louis, by contrast, insisted that there should be no provision for sharing scientific research. ${ }^{85}$ Disappointed at this, George W. had grasped at the straw that it was the informal exchange of ideas on manufacturing processes that was always for Rahway 'the thing of greatest value'. ${ }^{86}$

George W. Merck's ambitions had undoubtedly grown since the merger with PWR. He had recruited Randolph Major, a chemist from Princeton, to improve research into manufacturing processes. ${ }^{87}$ Major had encouraged George W. Merck to explore the possibility of vitamins production. ${ }^{88}$ The scientific discovery of vitamins and their isolation was one of the most significant developments in pharmaceuticals in the interwar period. Breakthrough discoveries were no longer just emerging from German laboratories, with important developments coming from France, the UK and Hungary as well as the U.S. But developing manufacturing capabilities in any of the newly discovered vitamins was far from straightforward. By 1932 E. Merck had become pioneers of vitamins manufacturing in Germany. By 1932 it was the market leader there in manufacturing Vitamin A (under the brand name 'Vogan') and Vitamin C ('Cebion'). ${ }^{89}$ So for George W. Merck the Treaty represented a significant step towards the ultimate prize of acquiring the scientific and manufacturing capabilities in producing vitamin specialties. The not inconsiderable risk he faced, however, was that any kind of agreement on restricting competition in export markets would be judged illegal in the United States. At the same time George W. was planning an expansion in in-house research capabilities at Rahway, with the decision to open the Merck Institute of Therapeutic Research. ${ }^{90}$

George W. took his time over the Treaty. His concerns in his correspondence with Darmstadt in early 1932 partly reflected the subdued state of the U.S. economy. ${ }^{91}$ But eventually the Treaty was signed in November 1932, 'I am pleased that we have all agreed with our difficulties so that we shall soon sign the Agreement', wrote Louis Merck to George W. in November 1932. ${ }^{92}$

The 'Treaty Agreement of November 17th 1932 ', summarized firstly the mutual rights to the Merck name in different overseas markets (Articles 1 and 2), and documents the pooling of technological knowledge between the two companies and the arrangement for profit sharing (Articles 5 and 6). There were other significant agreements between U.S. and overseas firms on technology sharing in the interwar period, but this was one of the most comprehensive. The Appendix initially contained a list of 250 products that were covered by the Treaty, rising to 432 products by $1939 .{ }^{93}$ While the Treaty undoubtedly restricted Merck \& Co.'s exporting opportunities, locking both parties into their respective 'spheres of influence', it gave Rahway an unprecedented opportunity to benchmark its manufacturing processes. ${ }^{94}$

Almost immediately after signing, Rahway staff methodically went through the list of processes, identifying those for which they wanted a detailed comparison with 
Darmstadt. One of Rahway's senior factory managers, R.P. Lukens, was dispatched to Darmstadt shortly after, visiting in May 1933. Lukens', and his Darmstadt equivalent, Dr Kulenkamff's, initial benchmarking exercise identified 46 of the 250 preparations where there were significant variations in cost or yield or method in the two factories. For these 46 processes the methods were exchanged and tested at both sites during June and July 1933. ${ }^{95}$ The detailed comparison of manufacturing processes for these 46 chemical preparations suggested that, on balance, in 1933 Darmstadt methods produced a superior yield, but Rahway's methods were relatively more efficient in their use of labour. 96

Lukens had also broached the topic of sharing early stage research findings during his stay. The Treaty of just a few months before had prohibited this. But Lukens reported that the response of the leading scientists at Darmstadt, Dr Fritz Merck, Dr Otto Dalmer (Head of Research) and Kulenkamff, was far more positive than that from Karl and Louis Merck had earlier been, and that the Darmstadt scientists' were 'willing to cooperate' in sharing research ideas. ${ }^{97}$ George W. Merck quickly followed this up with Karl Merck, suggesting that the two companies would 'place the results of their research mutually at the disposal of the contracting parties [both Mercks] on a broad scope. Nothing definite was laid down about the treatment of patents and trademarks pertaining to the products resulting from such research.' ${ }^{98}$ By March 1934 discussions had moved on to agree that 'patent data, i.e. scientific and technical features, are to be reported promptly to the contracting parties in connection with the regular exchange of research information. ${ }^{\prime 99}$ A Draft Agreement on Patents and Trademarks was also drawn up in 1934. While this was never formally executed, the exchange of intellectual property between the two Merck companies began in earnest. It was a highly unequal exchange. Between 1932 and 1940 at least 38 of Merck \& Co's U.S. patents filed were actually E. Merck inventions. Indeed, from 1937 to 193918 of Merck \& Co's 34 U.S. patents were actually Darmstadt inventions. By contrast, Merck \& Co. applied for zero patents in Germany before 1939.100

In the meantime George W. Merck had invested in a major new research building at Rahway and appointed Dr Hans Molitor (a pharmacologist from Vienna University) to direct the Merck Institute of Therapeutic Research which opened in June 1933 to herald the advent of basic physiological research within the industry. ${ }^{101}$ Molitor's role at Merck \& Co was crucial in establishing its scientific and research capabilities. Max Tishler, who went on to be head of research at Merck \& Co, insisted that Molitor and his leading of the Merck Institute's research programme in vitamins was of critical importance. It was Molitor along with Major and George W. Merck that decided the overall research programme. ${ }^{102}$

Molitor's initial research programme between 1934 and 1936 was focused on: anaesthetics, alkaloids, hypnotics, antispasmotics, vagomimetic and sympathomimetic drugs, vitamins (as food supplements), notably vitamin C. Later, from 1936, Vitamin B1 became increasingly important, so that by 1939 vitamin research overall accounted for half of all Merck Institute time. ${ }^{103}$ This initial research programme at the Institute did not emerge from a vacuum. But nor did it emerge from any pre-existing commitment to any particular research pathway within the firm. There were few pharmaceutical research commitments at Rahway of any significance facing Molitor when the Merck Institute opened in 1933. The company's commitment to research was modest until 
then, research expenditures were only 1.5 percent of sales in 1932 . The current literature views the opening of the Institute as the catalyst for the development of independent research capabilities within Merck \& Co. ${ }^{104}$ But Max Tishler later recalled that during his first few months after joining the company in 1937, he was aware that little actual research was done in the company. It was only by 1938 that the Merck Institute began conducting some 'fundamental as well as applied research'.105 There was very little basic research conducted internally at Merck \& Co before then. ${ }^{106}$ Merck \& Co's scientists hardly published in scientific journals at all in the early 1930s. Evidence of Merck \& Co's commitment to scientific publication in pharmaceuticals journals can only be seen from as late as $1938 .{ }^{107}$ Adolphe Rosengarten later made the point that all Merck \& Co's new products before the war had came from outside consultants, not from Merck \& Co's own scientists. ${ }^{108}$

If the Merck Institute was not therefore the catalyst for the creation of research capabilities at Merck \& Co until the very end of the 1930s, what did it do before then? A clue is found in Molitor's initial research programme at the Institute. This very closely maps onto the specialty areas selected for inclusion in the extension to the 1932 Treaty Agreement, agreed at two conferences in October and November 1934. This, the 'Protocol of Conferences between Rahway and Darmstadt with Regard to Researches and New Products', of November 1934, incorporated 35 new specialties into the Treaty. ${ }^{109}$

This 'Protocol' document bears close reading. It was the documentary outcome of the process begun by Lukens in the summer of 1933 in broaching the topic of sharing research, a feature which had been deliberately omitted from the 1932 Treaty at Darmstadt's insistence. If the technological competences of both contracting parties were approximately the same, then both stood to gain more or less equally from the Research Protocol. But Darmstadt were acutely aware that while Merck \& Co and E Merck enjoyed approximate parity in chemicals manufacturing expertise by the early 1930s, Darmstadt's expertise in research and specialties was far ahead of Rahway's. This is apparent from the list of 'researches and new products' covered in the Protocol. Out of thirty-five listed, only six were listed as Rahway developments, one of which, Vitamin B1, was included but, having only just been offered to Rahway by an external inventor, was too early to make judgments about. Of the 29 preparations emerging from Darmstadt, the products and technologies were focused on anaesthetics, improved alkaloids, hypnotics, antispasmotics, vagomimetic and sympathomimetic drugs, and of course vitamins, notably vitamin $C$ research, exactly the same areas as those prioritised by Molitor in the Merck Institute's initial research programme. ${ }^{110}$

Molitor had spent considerable time at Darmstadt on his appointment to the Merck Institute. Within weeks of his arrival at Rahway, George W. Merck was sending him back to Europe for an extended visit to Darmstadt. George W. wrote to Karl Merck at the end of October, that 'I was very glad that you counted the visit of Dr Molitor as beneficial to you; we certainly feel that it was on this side... to further the co-operation between our Companies.'111 Given the range of potential subject areas Molitor, Major and Merck might have chosen to prioritise in 1933, the overlap between exactly those areas prioritized by Molitor and the Merck Institute between 1934 and 1936 and the specialties offered by Darmstadt for the November 1934 extension to the 1932 Treaty, must lead to the very strong inference that Merck \& Co.'s research programme emerged 
from Molitor's extensive visits to Darmstadt. Molitor undoubtedly sanctioned other, non-Protocol related research in the Institute. ${ }^{112}$ But the selection of the Institute's research in the specialties made available to Rahway by Darmstadt was surely not a coincidence.

Unsurprisingly the number of visits between Rahway and Darmstadt increased after the 1934 Protocol and their character changed. Instead of the visitors being the most senior managers, from 1934 onwards the visitors were increasingly the senior scientists on both sides. From Merck \& Co it was increasingly Gruber and Molitor who visited Darmstadt and who hosted Dalmer and the other senior scientists from E. Merck. ${ }^{113}$ The first result was that Rahway's manufacturing capabilities in several respects caught up with those of Darmstadt between 1933 and 1938. Rahway's improvement in research capabilities followed.

The evidence of Rahway's improvement in manufacturing capabilities can be traced through specific product discussion between the two sites, and then successive benchmarking exercises. First, a February 1935 invitation to discuss Merck \& Co's lactic acid processes, led to an invitation for Darmstadt to 'explore the manufacture of Citric Acid by fermentation process from the point of view of any interest it may hold for E. Merck.' Recall that Vitamin C production was where Darmstadt was one of the world leaders. After benchmarking, Rahway's production processes were deemed to be superior, and this led in November 1936 to a separate agreement for ascorbic acid (bulk sales). ${ }^{114}$

During September 1937 there was a further revision to the range of products included in the Treaty. Out of the original 250, several were no longer being manufactured, but more significantly each firm had added to its total number of products. The revised list was titled, 'Processes operated by Merck \& Co., Inc. and E. Merck Darmstadt'. Just over 100 of the chemical processes listed were benchmarked in Darmstadt using both companies' techniques, following Lukens' original benchmarking methodology of 1933. The results suggest that while both companies were now approximately evenly divided in the relative cost advantages across the range of processes, Merck \& Co were now consistently outperforming Darmstadt in the yield attainment across the products tested. ${ }^{115}$ This in turn led to Merck \& Co sending to Darmstadt a list of 34 of Rahway's improved processes for articles included in the Treaty, and a further 12 processes for non-treaty articles, including for the first time Merck \& Co's sulfanilamide process.

In return Merck \& Co. requested 32 processes (mostly for the same products) to be sent from Darmstadt to Rahway for comparison, including Darmstadt's process for sulfanilamide. Lukens letter of December 6 ${ }^{\text {th }}, 1937$ to Darmstadt lists the 29 German processes received, including Darmstadt's process for aminobenzene sulfonamide. By 1938 Rahway's increasing capabilities at manufacturing even the newer specialties had become clear. In the subsequent revision to the Treaty, dated $10^{\text {th }}$ June 1938 , the new additions included three very significant new specialties: 'Ascorbic Acid (Vitamin C) and Tablets', 'Sulfanilamide (p-aminobenzene-Sulfonamide)', and 'Vitamin B1 (crystal, synthetic, natural and tablet)'.116

The inclusion of Vitamin B1 in the summer of 1938 is particularly significant because Vitamin B1 was Merck \& Co's own breakthrough product. Its arrival at Rahway, as the 
November 1934 Research Protocol had alluded to, was nothing to do with Merck \& Co's research programme. Molitor's vitamin research in 1933 and 1934, as already noted, was focused on Darmstadt's vitamin C processes. Instead Robert Williams, an independent researcher, employed by Bell Labs but with links to Columbia University, wanted to test his idea that vitamin B occurred naturally in rice husks. For this he required industrial scale rice polishing and testing facilities, hence his approach to Merck \& Co. Early results were sufficiently promising to lead to its inclusion as one of Rahway's few specialties in the Research Protocol list. It took another two years before the critical breakthrough of synthesizing Vitamin B1 was accomplished. But this was done by Merck \& Co's researchers, notably J.K. Cline. Then 'the door was opened for its economical and large scale production'.117 With some further months of development research required to establish a pilot and then a manufacturing plant, Merck launched vitamin B1 into the U.S. market at the end of 1937 and by 1940 it was generating significant revenues. In December 1941 the company highlighted the significance of Vitamin B1 sales in its prospectus to potential investors for a new stock offering. ${ }^{118}$ At this point Merck \& Co were happy to advertise that since 1936 its research had led to a host of new products, ranging from Vitamin B2, B6, C, E, G and K, as well as sulfonamides, but pride of place went to the increase in sales from Vitamin B1.

Vitamin B1 also changed the nature of the relationship with Darmstadt. As has been emphasized above, from the resumption of commercial relations in late 1921 through to the late-1930s, Rahway was unambiguously the junior partner. It had largely depended on Darmstadt technology, and it was only from 1928 at the very earliest that Darmstadt saw it was in their interests to allow Rahway increasing access to first manufacturing processes and then, from 1934, to its research and new specialties. Molitor seemingly focused the Merck Institute research programme exactly on those areas of new research that Darmstadt were willing to include in the November 1934 Research Protocol. The exchange of information on manufacturing processes contributed to improvements in manufacturing productivity on both sides, but notably led to Merck \& Co.'s improvement in yield seen by the end of 1937. Merck \& Co.'s manufacturing capabilities in chemical production were now, according to the benchmark data, consistently equal to and in many areas ahead of Darmstadt. Its research capabilities were also rapidly catching up.

The synthesis of vitamin B1 in 1936 and 1937 was the critical breakthrough that demonstrated to Darmstadt that Rahway had acquired some considerable scientific competence. While it did not initially lead to much interest from Darmstadt, the obvious commercial significance was such that Darmstadt went to some considerable lengths to acquire the European manufacturing rights. ${ }^{119}$ The agreement was finally signed in October 1939. Before then, during 1938 Darmstadt and Rahway decided to recognize the mutual contribution by each company to the other's vitamin business by terminating any future separate accounting for either Darmstadt's vitamin B1 sales or Merck \& Co.'s vitamin C sales. 'In the future E. Merck and Merck \& Co. will exchange manufacturing information on Vitamin B1 and Vitamin C without compensation'. 120 This then was surely the point when George W. Merck's strategy of replicating German manufacturing standards and internalising independent research capabilities at Rahway reached fruition. This was evidence of a near parity in the relationship between the two Mercks at last. 
But such intimate relations had a cost once the U.S. entered World War Two. The newly reformed Alien Property Custodian received an anonymous complaint that German spies were operating at Rahway in February 1942. ${ }^{121}$ This triggered a series of official investigations, first by the FBI, before the Alien Property Custodian once again became involved with Merck \& Co during the summer of 1942. It was at the beginning of these investigations that Perkin wrote his March 1942 memo to Federal Reserve Bank of New York setting out Merck \& Co's case that there had been since 1919 no 'interest..., control or influence' by E. Merck over Merck \& Co. The 1932 Treaty and its impact on Merck \& Co was described as 'relatively inconsequential'. The provisions in the Treaty on the mutual exchange of information were 'nothing more than the reduction to writing of common practice... simply a means by which each party endeavored to get the benefit of the other's manufacturing experience... nothing unusual in the arrangement to procure new production' from Darmstadt. ${ }^{122}$ The letter was carefully written, for while almost everything in it was credible, it deliberately downplayed the significance of the relationship with Darmstadt. It is noteworthy that none of the investigating agents of the APC or anti-trust investigation, or OMGGUS believed this version of events. All were convinced that the relationship between the two Merck companies was an unofficial and informal partnership, the extent of which had been deliberately obscured from the authorities in order to protect the private interests of the two companies. ${ }^{123}$

\section{CONCLUSION}

George F. Merck reacquired control of Merck \& Co in 1919. The terms of the APCmandated Trust were to ensure that Merck \& Co would be permanently severed from its former parent, E. Merck. The current literature suggests that Merck \& Co very largely complied with the terms of the Trust, that exchanges between the two Mercks, once the outstanding wartime financial issues were resolved, were limited to personal correspondence, some technical assistance and the correspondence to support the sale of a few Darmstadt manufactured products in the U.S. Previous studies have suggested that Merck \& Co. was entirely independent of any influence of its former German parent by sometime in mid-1920s. ${ }^{124}$ 'While some transfers of knowledge were probably recreated in the 1920s, the aftermath of the war was an increasingly independent American firm, Merck \& Co. Inc.' ${ }^{125}$ George F. Merck may have wanted to return to the pre-war business model. But the current view is of Merck \& Co's interwar evolution is that George W. Merck on assuming the presidency was set on a course of autonomy and independence. George W. Merck is remembered as a business leader unusual for being so farsighted, so focused on science and research, and not on profits. He is generally seen as being central to Merck \& Co.'s acquisition of independent research capabilities before 1940.126

But this interpretation underestimates Merck \& Co's continuing dependence on the larger E. Merck for access to the most advanced products in the interwar period. From the moment George F. Merck reacquired control of Merck \& Co. considerable efforts were made to re-engage with its former parent and re-establish the pre-war business relationship, regardless of the existence of the Trust. Nevertheless, the attempts to reestablish the pre-war business relationship were dashed between the Scylla of high U.S. tariffs and the Charybdis of Darmstadt's commitment to retaining central control of almost all manufacturing. As the two companies drifted apart, Merck \& Co's fortunes 
stagnated, forcing a merger with the larger Powers Weightman Rosengarten in 1927. This merger, almost paradoxically after years of stalemate, proved to be the catalyst which recreated the relationship between the two Mercks, leading to first several visits and exchanges of information, then to the 1932 Treaty, and the 1934 Protocol, and ultimately to the very significant transfer of technology from E. Merck to Merck \& Co.

The 1932 Treaty and its subsequent 1934 extension to include research and specialties (the Research Protocol) were therefore key events in the formation of Merck \& Co's independent research and advanced manufacturing capabilities. The treaty precipitated Lukens' successive benchmarking exercise from 1933 onwards, which, as the later benchmarking exercises confirm, show that Rahway's manufacturing capabilities were catching up with, and in several areas actually exceeded, those at Darmstadt by 1938. It is against the context of the Treaty and the Research Protocol that the recruitment of Major and Molitor, the establishment of the Merck Institute of Therapeutic Research and the Central Research Laboratories, and the bridges built with university scientists in the U.S. should be judged. From the November 1934 Research Protocol onwards, Merck \& Co.'s scientists gained privileged access to superior process and product technologies, enabling Rahway scientists to acquire insight and understanding of advanced research knowledge, routines and knowhow without having to do all the experimental work themselves.

The German influence at Merck \& Co was therefore more profound and much longer lasting than has hitherto been thought. While Merck \& Co. were expanding their internal research capabilities from 1933 onwards, the evidence on research expenditure, publications and patents presented here suggests that Merck \& Co's Rahway-based scientists were indeed beginning to move from focusing on developmental research to more fundamental pharmaceuticals research in the 1930s. But not only in the late 1930s, perhaps as late as 1937 and 1938. Judging from the patent data, where even as late as 1937 to 1939 over half of all Merck \& Co's U.S. patents were actually Darmstadt inventions, Merck \& Co's scientific and research capabilities still lagged behind those of E. Merck.

By contrast, the case of Merck \& Co suggests that where U.S. pharmaceuticals producers may have caught up and even overtaken German producers was in process technologies. Merck \& Co. was generating both additional yield and with greater labour efficiencies than E. Merck across most benchmarked processes by 1937 and 1938. Merck \& Co was one of the leading pharmaceutical companies in the U.S. war effort and went on to become one of the globally dominant producers after 1945 . The current view in the business history literature is that it acquired sufficiently sophisticated research and manufacturing capabilities by 1940 entirely through the decisions made by its senior management, notably George W. Merck, in creating its own internal research capacity. This view is not wrong. It is just incomplete. It is a view that is based on a detailed reconstruction of the company's relationship with its former parent in the 1920s, and the research presented here confirms that this relationship grew increasingly distant. But scholars have previously omitted continuing this research for the 1930s. Here, by contrast, and benefitting from access to previously unpublished sources from the extensive Darmstadt archive, we have been able to present a substantially more detailed account of the two companies' interwar relationship, and in particular to show how the merger with PWR led directly to a dramatic change and to 
much closer co operation. This growing closeness was embodied in the 1932 Treaty and the 1934 Research Protocol (and its subsequent revisions). When these documents are analysed in detail, it is clear that Rahway's research capabilities were far behind those of Darmstadt in the early 1930s. The imbalance of the 1934 Protocol demonstrates that. By 1938, however, after George W. Merck's substantial increase in research expenditures, after the establishment and growth of Molitor's Merck Institute, and also after recognising the sharing of knowledge between Rahway and Darmstadt, Rahway's research capabilities had improved significantly and they were justified in being considered among the leaders in the U.S. industry. The successful synthesis of Vitamin $\mathrm{B}_{1}$ and then its commercially successful launch was undoubtedly a breakthrough episode for Rahway.

The case of Merck \& Co therefore needs to be understood in the light it being the beneficiary of this substantial and previously ignored technology transfer from its former German parent. George W. Merck was indeed making every effort to replicate the Darmstadt model at Rahway, as scholars have previously noted. ${ }^{127}$ But his success in achieving these objectives was seemingly dependent on the transfer of technology and process know-how from Darmstadt. Because of Merck's position of leadership within the U.S. industry, this is a significant caveat to this important case. The conventional understanding is that the U.S. government's intervention during and after world war one allowed American firms to 'accumulate a pool of technical expertise through education and experience'.128 The caveat would be that for one of the most important American pharmaceutical firms, Merck \& Co, this accumulation of technical expertise was enormously augmented by support from its former German parent, E. Merck of Darmstadt. 
Table 1. Total US Patents - 1932-1939. Abbott Laboratories, Parke Davis, Eli Lilly and Merck \& Co.

\begin{tabular}{|l|l|l|l|l|}
\hline & Abbott & Parke Davis & Lilly & Merck \\
\hline 1932 & 4 & 1 & 4 & 0 \\
\hline 1933 & 5 & 1 & 2 & 1 \\
\hline 1934 & 6 & 3 & 4 & 1 \\
\hline 1935 & 3 & 4 & 9 & 3 \\
\hline 1936 & 2 & 2 & 3 & 6 \\
\hline 1937 & 9 & 10 & 5 & 6 \\
\hline 1938 & 5 & 6 & 8 & 11 \\
\hline 1939 & 3 & 8 & 9 & 17 \\
\hline Total & 37 & 35 & 44 & 45 \\
\hline
\end{tabular}

Source: Google Patents. Total of all US patents by year of publication from 01.01.1932 to 12.31.1939 by selected assignee firms (minus patents for equipment). Firms selected were the four largest U.S. firms (by capital employed in 1950 - see note 5 for source) that had been producing pharmaceuticals in the 1930s.

Table 2. Employment at E. Merck Darmstadt and Merck \& Co.

$\begin{array}{lll} & \text { E. Merck } & \text { Merck \& Co. } \\ 1895 & & 180 \\ 1904 & 1200 & \\ 1914 & 2100 & <800 \\ 1923 & 3600 & \\ 1925-30 & 3000 & \\ 1938 / 9 & 4100 & 1800 \\ 1940 & & 2200 \\ 1941 & & 3000\end{array}$

Notes and sources: Merck \& Co. 1914 inferred from Rosengarten interview p. 5 that PWR after WW1 employed 800, and that Merck \& Co., was both smaller than PWR and smaller in 1914 than after WW1. E. Merck employment data sources listed in note 35. Merck \& Co., in Sturchio and Galambos, Values and Visions, Appendix. 
Figures

Fig. 1. Patenting among US Pharmaceuticals Firms, 1932-1939 (assigned US patents by year of publication)
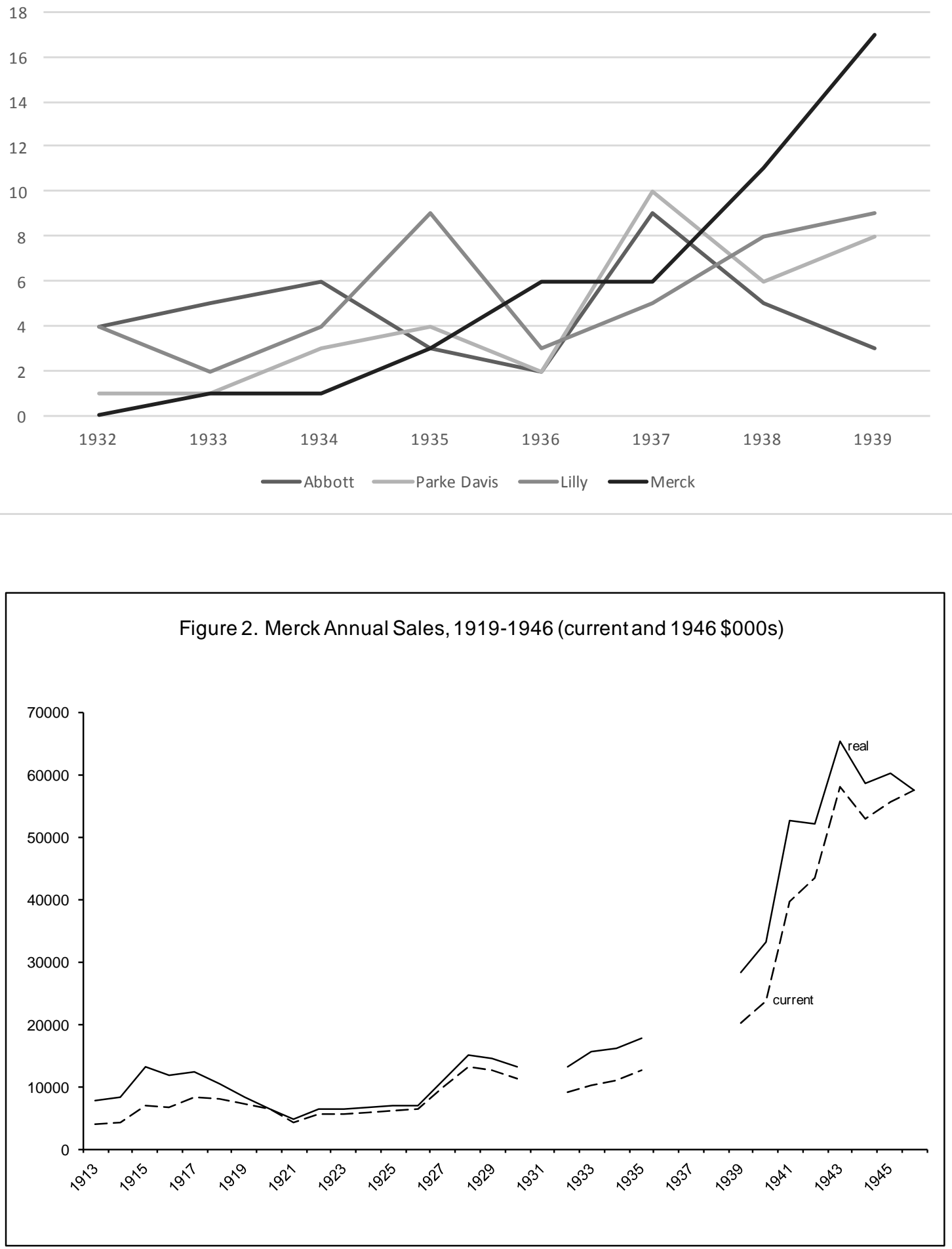

Source, Merck \& Co. Annual Reports various years and US Department of Labor, Bureau of Labor Statistics, Consumer Price Index. 


\section{REFERENCES}

Abbott Laboratories. The Abbott Almanac: One Hundred Years of Commitment to Quality Health Care, Elmsford NY: Benjamin Co., 1988.

Athreye, Suma and Andrew C. Godley. "Internationalisation and Technological Leapfrogging in the Pharmaceutical industry." Industrial and Corporate Change, 18, no. 2 (2009): 295-323.

Bayer. Fifty Years, 1888-1938, of Bayer Remedies. Leverkusen: Bayer/ IGF, 1938.

Beer, J.J. The Emergence of the German Dye Industry. Urbana, IL. 1959.

Bernschneider-Reif, Sabine, Walter Huber, and Ingunn Possehl. 'Was der Mensch thun kann...' The History of Merck - the World's Oldest Pharmaceutical Chemical Company. Darmstadt,: Merck KGaA, 2002.

Broadberry, Stephen. "The Performance of Manufacturing", in The Cambridge Economic History of Modern Britain eds Roderick Floud and Paul Johnson. Cambridge: University Press, 2004.

Bud, Robert. Penicillin: Triumph and Tragedy. Oxford: University Press, 2007.

Burhop, Carsten. "Pharmaceutical Research in Wilhelmine Germany: The case of E. Merck". Preprints of the Max Planck Institute for Research on Collective Goods, Bonn, 2008/ 3.

Burhop, Carsten. "Pharmaceutical Research in Wilhelmine Germany: The case of E. Merck". Business History Review 83 No. 3 (2009): 475-503.

Cantwell, John A. "Historical trends in international patterns of technological innovation," in New Perspectives on the late Victorian economy ed. James Foreman-Peck. Cambridge: University Press, 1991.

Carlisle, Robert D., A Century of Caring: The Upjohn Story Benjamin Press, Elmsford NJ. 1987.

Carstensen, Fred. "Liggett, Louis", American National Biography, New York and Oxford, Oxford University Press, 1999, volume 13, pp. 645-646.

Chandler, A.D. Visible Hand. Harvard MA: Belknap Press, 1977.

Chandler, A.D. Scale and Scope. Harvard MA: Belknap Press, 1990.

Chandler, A.D. "The Competitive Performance of U.S. Industrial Enterprises since the Second World War," Business History Review 68 No. 1 (Spring 1994): 1-72.

Chandler, A.D. Shaping the Industrial Century: The Remarkable Story of the Evolution of the Modern Chemical and Pharmaceutical Industries. Cambridge MA: Harvard University Press, 2005.

Church, Roy and E.M. Tansey, Burroughs Wellcome: Knowledge, trust, Ptofit and the Transformation of the British Pharmaceutical Industry, 1880-1940. Lancaster: Crucible Books, 2007.

Corley, T.A.B and Godley, A.C. 2011. The Veterinary Medicines Industry in Britain, 19002000, Economic History Review, 64 (3): 832-854.

Cramer, Tobias. "Building the 'World's Pharmacy': The Rise of the German Pharamceutical Industry, 1871-1914," Business History Review 89 vol. 1 (2015): 45-73.

Davies, Wyndham. The Pharmaceutical Industry: a personal study. Oxford: Pergamon Press, 1967.

Deeson, Tony. Parke, Davis in Britain, The First hundred years. Eastleigh, Parke Davis ltd., 1995.

Derdak, T. Ed. International Directory of Company Histories. London: St James Press, 1988.

Egan, John W. The Economics of the Pharmaceutical Industry London: Praeger, 1982. 
Finucane, Brendan T. "Canadian contributions to the introduction and use of divinyl ether," Canadian Journal of Anesthesia 55 No. 12 (2008): 853-858

Fisher, J. C. "Basic Research in Industry," Science 129 No. 3364 (1959): 1653-1657.

Franko, Lawrence, The European Multinationals: A Renewed Challenge to American and British Big Business, Harper \& Row, London, 1976.

Frontline various issues, for instance, 14 (Jan-Feb) 1969, 20 (Mar/April, 1970), Merck Archives.

Furman, Jeffrey L. and Megan J. McGarvie. "Academic Science and the birth of industrial research," Journal of Economic Behavior and Organization 63 (2007): 756-776.

Galambos, Lou and Jane Sewell, Networks of Innovation: Vaccine Development at Merck, Sharp and Dohme, and Mulford. Cambridge: University Press, 1995.

Galambos, Lou and Jeffrey Sturchio, "The Pharmaceutical Industry in the Twentieth Century: A reappraisal of the sources of innovation," History and Technology 13 (1996): 83-100;

Galambos, Lou and Jeffrey Sturchio. "Transnational Investment: the Merck Experience, 1891-1925," Zeitschrift fur Uniternehmergeschichte 81 (1994): 227-243.

Galambos, Lou and Jeffrey Sturchio, 'Sustaining Innovation: Critical Transitions at Merck \& Co., Inc.', unpublished ms, August 8, 1997.

Gambardella, Alphonse. Science and Innovation: The U.S. Pharmaceutical Industry during the 1980s. Cambridge: University Press. 1995.

Grilliches, Zvi. "Patent Statistics as Economic Indicators: a survey," Journal of Economic Literature 28 (1990): 1661-1707.

Haber, L.F. The Chemical Industry during the Nineteenth Century Oxford: University Press, 1958.

Hannah, Les. "Logistics, Market Size, and Giant Plants in the Early Twentieth Century: A Global View," Journal of Economic History 68 No. 1 (2008): 46-79.

Hertner, P., 'German multinational enterprise before 1914: Some case studies,' in P. Hertner and G. Jones (eds), Multinational Enterprise: Theory and History (1987), pp. 113-13

Hounshell, David A., and John K. Smith. Science and Corporate Strategy: Du Pont R\&D 1902-1980 Cambridge: University Press, 1988.

Hugill, Peter J. and Veit Bachmann. "The Route to the Techno-Industrial World Economy and the Transfer of German Organic Chemistry to America before, during and immediately after World War," Comparative Technology Transfer and Society 3 No. 2 (2005): 158-186.

Indianapolis Star (Edelhart, Courtenay). "The economy: Eli Lilly \& Co. A Firm Foundation," Indianapolis Star 18th April 1999.

Kahn, EJ. All in a Century. The First 100 Years of Eli Lilly and Company. Indianapolis: Lilly, 1975.

Kline, Ronald. "Constructing 'Technology' as 'Applied Science'” Public Rhetoric of Scientists and Engineers in the United States, 1880-1945," Isis, 86 vol. 2 (1995): 194-221.

Kobrak, Christopher. "Issues in German Corporate Governance: A Note on the history of Schering AG and the culture of German Capitalism," paper presented to European International Business Academy, Stockholm, Sweden, December, 1996.

Kobrak, Christopher. National Cultures and International Competition: the Experience of Schering AG, 1851-1950. Cambridge: University Press, 2002.

Kogan, Herman. The Long White Line: The Story of Abbott Laboratories. New York: Random House, 1963. 
Lamoreaux, Naomi and Kenneth Sokoloff. "The Rise and Decline of the Independent Inventor: A Schumpeterian Story?" in Challenge of Remaining Innovative, eds Sally Clarke, Naomi Lamoreaux, and Steve Usselman, Stanford: University Press, 2009: 43-73.

Lee, Jeho. "Innovation and Strategic Divergence: An Empirical Study of the U.S> Pharmaceutical Industry from 1920 to 1960," Management Science 49 No. 2 (2003): 143-159.

Lesch, John. The First Miracle Drugs. How Sulfa Drugs Transformed Medicine, Oxford University Press, Oxford, 2007.

Liebenau, Jonathan. "Industrial R\&D in Pharmaceutical Firms in the Early Twentieth Century," Business History 26 No. 3 (1984): 329- 346.

Liebenau, Jonathan. Medical Science and Medical Industry: The Formation of the American Pharmaceutical Industry. Basingstoke: Macmillan, 1984

Liebenau, Jonathan. "Patents and the Chemical Industry: tools of business strategy," in Jonathan Liebenau ed. The Challenge of New technology. Innovation in British Business since 1850 Aldershot: Gower, 1988.

Liebenau, Jonathan. "Detail men: marketing medicine," in R.P.T. Davenport-Hines, ed., History, Bagmen and Markets Aldershot: Gower, 1986.

Liebenau, Jonathan. "Modernizing the Business of Health" Pharamceuticals in Britain, in comparison with Germany and the USA, 1890-1940," Industrial and Corporate Change, 22 No. 3 (2013): 807-847.

Lynn, Matthew. The Billion Dollar Battle: Merck versus Glaxo London: Heinemann, 1991. Madison, Eli Lilly.

Mahoney, Tom. Merchants of Life. An Account of the American Pharmaceutical Industry Harper, New York, 1959.

Marion, John F. The Fine Old House. Philadelphia: SmithKline Corporation, 1980.

Merck Annual Reports, various years, Merck Archives.

Merck Review, various issues, Merck Archives.

Mines, Samuel. Pfizer... An Informal History. New York: Pfizer Inc., 1978.

Mowery, David and Nathan Rosenberg. Technology and the Pursuit of Economic Growth. Cambridge: University Press, 1989.

Opie, Robert. Colgate Palmolive in the U.K. 75 Years of Care. Guildford: Colgate-Palmolive (UK) Ltd., 1997.

Owens, Larry. "MIT and the Federal 'Angel': Academic R\&D and Federal-Private Cooperation before World War II", Isis 81 vol. 2 (1990): 188-213.

Quirke, Vivienne. "Anglo-American Relations and the Co-Production of American 'Hegemony' in Pharmaceuticals." In H. Bonin and F. de Goey eds. American Firms in Europe, 1880-1980. Strategy, Identity, Perception and Performance Geneva: Droz, (2009): 363-384.

Quirke, Vivienne. Collaboration in the Pharmaceutical Industry. Changing Relationships in Britain and France, 1935-1965. Routledge, Abingdon, 2008.

Rasmussen, Nicolas. "Making the First Anti-Depressant: Amphetamine in American Medicine, 1929-1950" Journal of the History of Medicine and Allied Sciences 61 No. 3 (2006): 288-323.

Rodengren, J.L. The Legend of Pfizer. Write Stuff, Fort Lauderdale, FL., 1999.

Sanderson, Michael. "Research and the Firm in British Industry, 1919-39," Science Studies 2 (1972): 107-51.

Scheiding, Tom. "Building the Scholalry Society Infrastructure in Physics in interwar America," Studies in History and Philosophy of Modern Physics 44 (2-13): 450-463. 
Schneider, Michael. "Das Wissenschaftlichen Unternehmen. Zur chemischpharmazeutischen Forschung bei E. Merck, Darmstadt, ca. 1900-bis 1930," Zeitschrift fur Unternehmengeschichte 62 vol. 2 (2017): 163-203.

Sharp \& Dohme, "The History of Sharp \& Dohme: from apothecary shop to international institution," no author, no date but c. 1946. Merck Archives.

Shook, Robert. Miracle Medicines.

Slinn, J. A History of May \& Baker, 1834-1984. Hobsons, Cambridge, 1984.

Slinn, J. Abbott Laboratories in the UK. Granta, Cambridge, 1999.

Slinn, J. Patents and the UK pharmaceutical industry between 1945 and the 1970s, History and Technology 24 No. 2 (2008): 191-205.

Steen, Kathryn. The American Synthetic Organic Chemicals Industry: War and Politics, 1910-1930, UNC Press, Chapel Hill NC., 2014.

Sturchio, Jeffrey and Lou Galambos. Values and Visions. A Merck Century Merck \& Co. Inc, Whitehouse Station, NJ., 1991.

Sturchio, Jeffrey and Lou Galambos, "The German Connection: Merck and the Flow of Knowledge from Germany to the United States, 1880-1930," Business and Economic History On-Line Vol. 9 (2011): 1-14.

Swann, John P. Academic Scientists and the Pharmaceutical Industry: Co-operative Research in Twentieth Century America. Baltimore MD: Johns Hopkins University Press, 1988.

Temin, Peter. "Technology, regulation, and market structure in the modern pharmaceutical industry," Bell Journal of Economics 1979: 429-446.

Time magazine, various issues, including Aug 29th, 1929. Time 'Drug Disinc', 1932. Time magazine, August 26th, 1929.

Ulyott, Glenn E., Barbara Hodsdon Ullyot, and Leo Slater. "The Metamorphosis of SmithKline \& French Laboratories to Smith Kline Beecham: 1925-1998," Bulletin of the History of Chemistry 25 No. 1 (2000): 16-20.

White, Michael. "US Alien Property Custodian patent documents: A legacy prior art collection from World War II - Part 1. History," World Patent Information 29, Issue 4 (2007): 339-345.

Wilkins, Mira. The History of Foreign Investment in the United States, 1914-1945. Cambridge MA.: Harvard University Press, 2004.

Archival sources:

Chemical Heritage Foundation, Philadelphia, PA, US.

Merck KGaA, Archives, Darmstadt, Germany.

Merck \& Co., Inc. Whitewater Station, NJ, US.

US National Archives, MD, US. 
${ }^{1}$ Steen, American Synthetic Organic Chemicals.

2 Liebenau 'Detail Men', Fig 8.5, p.143 and p. 144. By 1910-12 German intellectual property was dominant in the US. In the sub-field of organic colors, for example, Bayer, BASF and Hoechst together owned two-thirds of all German-held U.S. patents. Cantwell 'Evolution', p. 17;.

${ }^{3}$ On the earlier attempts to form an ethical trade, see Galambos and Sewell, Networks, p. 18; and Rosengarten interview, p. 8 on MDs' mistrust of 'patent' medicine producers. On Abbott, see Swann, Academic Scientists, pp. 59-65; Kogan, Long White Line; Abbott, Almanac. Swann, Academic Scientists, p. 36, states that Abbott was the 'most successful' at replacing German products. George W. Merck writing to his Darmstadt cousin, Karl Merck, in 1922, stated that Abbott was 'the most aggressive in manufacturing the former German specialties such as Veronal (Barbital), Atophan (Concophen) and Novocain (Proccaine).' He went on though to underline what Abbott had done that was genuinely unusual by saying that, 'Butyn, however, they seem to have worked out themselves.' $5^{\text {th }}$, April, 1922, E. Merck Archives (EMA), Darmstadt, A1032.

${ }^{4}$ Steen, American Synthetic Organic Chemicals, pp. 247-259, esp. T. 8.1, 8.2 and 8.3. US producers of synthetic dyes responded to the German absence much more quickly. ${ }^{5}$ Slinn, Abbott, p.47-48 lists the firms in order of total capital employed. Also see Church and Tansey, Burroughs Wellcome, p. 413. The eight largest U.S. firms had over half the total market, Abbott, Almanac, p. 152. Mahoney, Merchants, and Derdak, Directory, give good short overviews of each. Only Hoffmann-La Roche headquartered outside the U.S. could rival the largest five for size at this time, and Hoffmann's success was based on its U.S. subsidiary. US producers' market share rose from approximately $10 \%$ of world exports in 1929 to $50 \%$ by the 1950s, Broadberry, 'Performance of Manufacturing', Table 3.8, p. 76.

6 Steen, American Synthetic Organic Chemicals, Conclusion, pp. 287-293.

${ }^{7}$ Chandler, Shaping, pp. 9-10. Liebenau asserts that the scale of industry R\&D increased during the 1920s, Medical Science, p. 35. But Lee, 'Innovation and Strategic Divergence', and Furman and McGarvie, 'Academic Science and the birth of industrial research', pp. 761-2 point to the 1930s as the key period of expansion in pharmaceutical research activities. Others also suggest advances in the 1920s were relatively inconsequential: Kobrak reports that Schering's directors concluded that Parke, Davis had few competitive products or underlying capabilities in 1929, for instance, Kobrak, National Cultures, pp. 169-70. Kobrak also suggested that US manufacturing capabilities in the 1920s were insufficient for pharmaceutical producers to take advantage of German patents, Kobrak, 'Issues in German Corporate Governance', p. 16. On the growing links between university scientists and pharmaceutical companies, see Swann, Academic Scientists, who emphasizes that university and institute based scientific capabilities were far more advanced than among US company in-house research staff. Also see Lesch, Miracle Drugs, on Johns Hopkins. Lesch also emphasizes the institutional constraints on medical research in the U.S. compared with Germany, esp. pp. 21-34. George W. Merck's 1922 observations cited above on what was unusual about Abbott continued, 'What interests me particularly is the splendid cooperation they seem to have gotten from the American Medical Association. This we must not expect to get,' George W Merck to Karl Merck, 5th April, 1922, EMA A1032. When George W. Merck hired Alfred Newton Richards from Yale in 1930, Richards was forced to defend his 
academic reputation, declaring that Merck shared similar values, that 'I saw in them no sign of the horns or tail', Sturchio and Galambos, Values and Visions, p. 23. Furman and MacGarvie, 'Academic Science', shows university-industry collaboration did increase, but only after 1938. For the growth of university-industry research collaboration more generally see, Kline, 'Constructing "Technology"'; Owens, 'MIT and the Federal "Angel”'; and Scheiding, 'Building the Scholarly Infrastructure'.

${ }^{8}$ Swann, Academic Scientists, p. 36; Slinn, Abbott, p. 11. Kogan, Long White Line, p.148, for Abbott R\&D and sales data. Its annual sales were $\$ 4.0 \mathrm{~m}$ in $1931-1933$, rising to $\$ 7.6$ million by 1936 , and then further to $\$ 9.5 \mathrm{~m}$ in 1937 . Abbott, Almanac, p. 10 on its research center.

${ }^{9}$ Kobrak, National Cultures, p. 171. This may have been an exaggeration, as the context was a discussion between Schering and Lilly senior management about relative research strength as a prelude to a possible alliance. In 1934 Lilly had a research and control staff of seventy, or two-and-a-half times that of Abbott's. But Lilly's sales were more than three times bigger than Abbott's, reaching over $\$ 13$ million in 1932. Swann, Academic Scientists, p. 36 for Lilly research staff; 1932 sales from Indianapolis Star $18^{\text {th }}$ April 1999; post-1932 sales growth inferred from Madison, Lilly.

101929 to 1936 inclusive and 1940 calculated from Sturchio and Galambos, Values and Visions, Appendix. In 1936 research expenditure is listed, but not sales, so 1935 sales has been used as the denominator. 1938 and 1939 from 'Prospectus, December 1941', RG131. Research expenditures then fell to 3.9\% of sales in 1941, from Perkin to Blauvelt, March 1942, RG131.

${ }^{11}$ Squibb began the interwar period with a 'handful' of researchers, rising to 'over fifteen' by 1928 and a research budget of $\$ 200,000$ per annum, rising to $\$ 210,000$ in 1929. But with total sales at over $\$ 13$ million, research expenditure was less than $1 \frac{1}{2} \%$ of sales. Swann, Academic Scientists, pp. 36, 50; Time magazine, August 26 ${ }^{\text {th }}, 1929$. Smith, Kline French were enjoying sales of around $\$ 8 \mathrm{~m}-\$ 9 \mathrm{~m}$ by the mid-1930s, but their research budget was only $\$ 70,000$, or less than $1 \%$ of sales, and employing only eight research staff. Swann, Academic Scientists, p. 38. With sales of \$7 million Upjohn employed 15 research staff in 1932, essentially for control purposes only. Carlisle, Century, pp. 49, 73 and 79. American Home Products expenditure on research only reached $1.1 \%$ of its sales as late as 1941 . 'American Home Products Corporation, Historical Data', RG131 Foreign Funds Control General Subject Files. 1942-1960, Box 400. Sharp and Dohme even after a rapid increase in research expenditure from 1937 still spent less than 2\% of sales on R\&D in1940. Sharp \& Dohme, Annual Reports, 1938 to 1941, MA. The big omission here is of course Parke, Davis, for which we have been unable to locate any data.

${ }^{12}$ For comparative industry commentary on Merck see, Furman and McGarvie,' p. 769; Madison, Lilly, pp. 51-67, 91-95; Mines, Pfizer, 13-24, 51-61, 68-90. Sturchio and Galambos, 'German Connection', 2011, 'the firm became one of the leaders in the American industry in the 1930s and 1940s', p. 14; Steen, American Synthetic Organic Chemicals, Merck was one of the leaders 'By 1930', p. 246.

${ }^{13}$ Steen, American Synthetic Organic Chemicals, ch. 8.

${ }^{14}$ Steen, American Synthetic Organic Chemicals; Wilkins, History of Foreign Investment, also mentions Boehringer acquired a controlling stake in a U.S. firm, pp. 252, 416.

Kobrak, National Cultures, after several years of Schering operating a subsidiary there clandestinely, pp. 160-2.

15 Whereas the U.S. subsidiary of the Swiss Hoffman La Roche was included in the crash penicillin program. Shook, Miracle Medicines, p. 302. 
${ }^{16}$ Steen, American Synthetic Organic Chemicals, p. 292, does emphasize the significance of gains in manufacturing productivity in the US industry.

17 Cramer, 'Building the "World's Pharmacy"', Table 1, p. 48. Lesch, Miracle Drugs, pp. 15-50.

${ }^{18}$ Bernschneider-Reif et al, Was der Mensch, pp. 46-9, 64-5.

19 Gortler, 'Merck in America', pp. 1-2; Galambos and Sturchio, 'The German Connection', pp. 7-9. Theodore Weicker and George F. Merck were the two US partners, both having worked in Darmstadt for the parent company for several years. Weicker had joined the Darmstadt company as a seventeen year old in 1878, left to take over the U.S. agency in 1887 before becoming a partner in the 1891 subsidiary. He eventually left to become the President of Squibb in 1905, which he transformed into one of the leading U.S. pharmaceuticals businesses. Also see George W Merck to Louis Merck on Weicker, $11^{\text {th }}$ October, 1932, B/29b (and replies from Louis $4^{\text {th }}$ November and $14^{\text {th }}$ November, 1932), EMA.

${ }^{20}$ Liebenau, Medical Science, p. 34, lists the 'large wholesalers/ producers' as: 'Merck, Smith Kline, Parke Davis, Eli Lilly, Sterns, Schieffelin, John Wyeth, Upjohn, Mulford, Sharp and Dohme'. Employment figure from Galambos and Sturchio, 'Transnational Investment', p. 233. Liebenau, Medical Science, p. 32 on SmithKline employment. 21 SmithKline sales 1902, Liebenau Medical Science p. 147; product lines Frontline 14 (Jan-Feb) 1969, MA.

${ }^{22}$ Galambos and Sturchio, 'Transnational Investment', pp. 240, 238 (citation); Gortler, 'Merck in America', pp. 1-2; and Bernschneider-Reif et al, Was der Mensch, p. 53 states the German price list in the 1890s contained around 10,000 different items - by the 1900s it had more. Merck \& Co 1910 sales from Sturchio and Galambos, Values and Visions, p. 15.

${ }^{23}$ Lesch, Miracle Drugs, pp. 15-50 on German firms' commitment to a much bigger scale of investment in R\&D. Haber, Chemical is the classic reference on the German Chemicals and Beer, Emergence, on the German R\&D model.

${ }^{24}$ Liebenau, 'Industrial R\&D', pp. 335-341; Hannah, 'Logistics, Market Size', p. 70;

Davies, Pharmaceutical Industry, pp. 1-2 and 10; Bayer, Fifty Years, pp. 27-39, 68; Slinn, May \& Baker, p. 91.

25 Schneider, 'Das Wissenschafliche Unternehmen'; Bernschneider-Reif et al, Was der Mensch, p. 53; Burhop, 'Pharmaceutical Research'.

${ }^{26}$ Burhop, 'Pharmaceutical Research', pp. 482-3. Smaller companies typically also relied on collaboration with university scientists. Schering, for instance, spent very little on inhouse research, instead collaborating with several Berlin-based professors. Schering in Liebenau, 'Detail Men', pp. 34-5; Burhop, Table 1, p. 487; Kobrak, National Cultures, lists Schering R\&D expenditure and payments to university scientists, pp. 37-8, 118-120. The 1911 founding of the Kaiser Wilhelm Institute (later Max Planck Institute) in Biology had a beneficial impact on the German industry in the interwar period, Quirke, Collaboration, p. 25.

27 Research expenditure and sales figures from Burhop, 'Pharmaceutical Research', pp. 482-3. 1902-5 average research expenses 190,000 marks (of which 80,000 went as payments to university researchers) and average sales were 11.5 million marks. By 1912 E. Merck payments to university researchers increased to 300,000 marks.

Assuming the other components of R\&D expenditure increased at a similar rate leads to a R\&D expenditure of 712,500 marks, and total sales in 1912 of 23m marks.

${ }^{28}$ Burhop, 'Pharmaceutical Research', Table 2, p. 489. Bernschneider-Reif, Was der Mensch, p. 86, 'extraordinarily high growth rates' for E. Merck's pharmaceuticals during 
and after the war. Schering's successful diversification into pharmaceuticals was similarly dependent on a handful of products. Kobrak, National Cultures, Table 8, p. 364, shows that 74\% of Schering's pharmaceutical sales came from just two products in $1913,66 \%$ of sales from just three products in 1928.

${ }^{29}$ Hertner, 'German multinational enterprise before 1914'.

${ }^{30}$ Burhop, 'Pharmaceutical Research', pp. 480-492; Bernschneider-Reif et al, Was der Mensch, p. 53. Liebenau, Medical Science on Veronal in U.S. c. 1917, pp??.

31 Wilkins, Foreign Investment, pp. 404-417. Hugill and Bachmann, 'Techno-Industrial World Economy'; Steen, American Synthetic Organic Chemicals; Bernschneider-Reif et al, Was der Mensch, pp. 80, 82, 84.

32 Bernschneider-Reif et al, Was der Mensch, p. 86. Cramer shows that branded specialties were the most profitable but low volume business before 1914, 'Building the "World's Pharmacy"', Tables 2 and 3, pp. 60 and 68.

33 Bernschneider-Reif et al, Was der Mensch, pp. 73, 86-7, 97, 94, 101.

${ }^{34}$ Schneider, 'Das Wissenschafliche Unternehmen'. This increase in research intensity was a general feature in Germany. Schering increased its commitment to industrial research during the 1920s, with total R\&D expenditure reaching around 3.5\% of total sales, and perhaps approaching 7\% of pharmaceutical sales in 1929. Kobrak, National Cultures, pp. 118-121 mentions in-house R\&D expenditure reaching nearly RM $1 \mathrm{~m}$ in 1929, but payments in fees to scientists being another RM 400,000 on top (this for 1927). Total 1929 sales were RM 40.2m. Pharmaceutical sales were $45 \%$ of this, so assuming that research was overwhelmingly concentrated on pharmaceuticals, the R\&D intensity of Schering's pharmaceuticals operations by 1929 was closer to $7 \%$ of (pharmaceutical) sales. Schering saw E. Merck as their closest rival, ibid., p. 43. Franko, European Multinationals, p. 25. The successor to Bayer, IG Farben, had continued with Bayer's industrial research model. In 1927 it spent a remarkable $12.7 \%$ of total sales on R\&D. Sanderson, 'Research and the Firm', n. 11. Burhop, 'Pharmaceutical Research [Max Planck version]', p. 24, on Merck and Hoechst in-house R\&D expansion after World War 1; and Bayer, Fifty Years, p. 12. These are of course fragmentary data but are worth comparing with the equally spotty data for interwar US research intensity noted above (see notes 9, 10 and 11).

35 Schneider, 'Das Wissenschafliche Unternehmen'; Bernschneider-Reif et al, Was der Mensch, pp. 94-95, 101.

${ }^{36}$ Kobrak, National Cultures, p. 44 (1913); Franko, European Multinationals, p. 36 (1939).

${ }^{37}$ Merck \& Co. was fully incorporated in the state of New York in 1908. BernschneiderReif et al, Was der Mensch, p.73; Gortler, 'Merck in America', p. 2.

38 Indeed, Garvan even purchased the remaining unsold former German patents and trademarks and donated them to the newly formed Chemical Foundation. Wilkins, History of Foreign Investment, pp. 49-50; Steen, American Synthetic Organic Chemicals; and Lesch, Miracle Drugs, pp. 26-36.

${ }^{39}$ Steen, American Synthetic Organic Chemicals is excellent on the APC. Wilkins, History of Foreign Investment, pp. 129 ff. on Garvan, p. 133 on his anti-German bias. For details see the two official reports on George F. Merck: 'Report on Examination 1.1.14 to 9/30/19 of Merck \& Co.' by C.D. Giles to Bureau of War Intelligence, Feb 21st, 1919; and 'Supplemental Report 1/1/14 - 9/30/18 of Merck \& Co.' by Greeley \& Giles to the Alien Property Custodian, Francis P Garvan, Feb 27th, 1919, both in Record Group 131, Records of Alien Property, U.S. National Archives (hereafter RG 131 RAP). Also see 'Letter from Special Counsel of Division of Insurance to General Counsel, Bureau of Law, 
Alien Property Custodian, November 2, 1918', and 'Francis P. Garvan to Advisory Sales Committee, June 5, 1919', both in RG 131 RAP. Galambos and Sturchio, 'Transnational Investment', touch on this, p. 240.

40 Steen, American Synthetic Organic Chemicals. Gortler, 'Merck in America', p. 2; Galambos and Sturchio, 'Transnational Investment', p. 240 mention that Monsanto and American Aniline were two of the other three bidders. Merck \& Co.s success during WW1 guaranteed bidders, see 'Garvan to Advisory Sales Committee'.

41 'Garvan to Advisory Sales Committee'.

42 'Trust Agreement..., July 23'rd, 1919', RG 131 RAP. Personal ties were permitted to continue of course, but commercial correspondence was supposed to be restricted to organising the formal separation. Galambos and Sturchio, 'Transnational Investment', p. 241 and n. 53, p. 241.

${ }^{43}$ Galambos and Sturchio, Values and Vision, pp. 15-17. It is, in fairness to the authors, barely mentioned.

${ }^{44}$ Galambos and Sturchio, 'Transnational Investment'.

45 Galambos and Sturchio, 'Transnational Investment', p. 241.

${ }^{46}$ Galambos and Sturchio, 'Transnational Investment', pp. 241-2. Note 54, p. 242, refers to correspondence dated 1921 as the source. Note 56 states that the 'conclusion to this phase of the relationship... actually falls outside of our time period for this essay', which may explain why the dramatic rekindling of the relationship in the 1930s was missed. 47 George Perkins to C. D. Blauvelt, Federal Reserve Bank of New York, 21 st March, 1942. RG131, Box 400, folder 'Schering Corp (to be)', citation p. 8. Note that Perkins mistook the length of the period the Trust was to operate, suggesting it was only five and not ten years. Our thanks to Mira Wilkins for alerting us to this source, which she cites in History of Foreign Investment, n. 315, p. 819. Perkins was a key figure in the development of Merck, whose contribution has not been fully recognized. See Lean Gortler, 'Interview with Adolphe Rosengarten', Merck \& Co. Archives (MA).

${ }^{48}$ Galambos and Sturchio, 'German Connection', p. 10.

${ }^{49}$ Galambos and Sturchio, 'German Connection', p. 12.

${ }^{50}$ Galambos and Sturchio, 'German Connection', p. 12.

${ }^{51}$ Galambos and Sturchio, 'German Connection', p. 11.

52 Galambos and Sturchio, 'German Connection', p. 14.

53 The best additional histories being Gortler, Merck in America'; and Steen, American Synthetic Organic Chemicals.

${ }^{54}$ Merck \& Co Archives (at Whitehouse Station NJ) henceforth indicated as MA. E. Merck Archives, Darmstadt, henceforth EMA. Note we have of course depended extensively on official reports based at the US National Archives as well as corporate archives and other sources.

55 Cablegram, George F. Merck to E. Merck, Darmstadt, Sept, $12^{\text {th }}$ 1919, MA.

56 George W Merck to Karl Merck, 24.12.1920. EMA folder E10.

57 Kobrak, National Cultures, pp. 143-4, 150-1, 159, and Table 13, p. 369.

58 Kobrak, National Cultures, pp. 159-60.

59 This is covered very carefully in two important reports. First, Division of Investigation and Research, 'Merck \& Co. Inc.: Memorandum to The Executive Committee of the Office of the Alien Property Custodian,' 28 ${ }^{\text {th }}$ February, 1944. RG131/ 230/38/34/07 Foreign Funds Control Documents, Box 11 'Merck' folder, p. 3. Second, Office of Military Government for Germany (U.S.) (OMGGUS) Division of Investigation of Cartels and External Assets, 'Report on Investigation of E. Merck, Darmstadt', $6^{\text {th }}$ November 1945, pp. 38-40. This also states that George W. Merck was also permitted by the APC to keep 
an additional $\$ 538,128$ which were owed to him by E. Merck. RG 151, Records of the Bureau of Foreign and Domestic Commerce, Office of International Trade European Division, NC3-151-80-3, Box 3, Folder 'E Merck'. After the final settlement in 1924, with additional taxes and costs deducted, Darmstadt received only around $\$ 1$ million of the $\$ 3.75$ million paid by George F. Merck and his consortium for their $80 \%$ share of Merck \& Co. OMGGUS 'Report', p. 39, with another $\$ 500,000$ to E. Merck's fellow cartel members, Boehringer, Gehe and Knoll.

60 OMGGUS 'Report', pp. 39-44. Also see George W. Merck to Karl Merck, letter 30th January 1922, EMA A1032. It is a further curiosity that given E. Merck's 1913 sales revenues, its likely valuation in 1917 would have been significantly greater than the $\$ 3$ million implied by the $\$ 600,000$ balance of the compensation that George F. received for the $19 \%$ interest in the German parent he lost.

61 OMGGUS 'Report', pp. 43-4 on the 'oral' agreements. Oscar Ewing's (Merck \& Co.'s counsel) testimony to Anti-Trust investigators on May 31'st, 1945 disclosed for vesting a further six licensing agreements between the two Mercks that had operated between 1921 and 1932. See Office of the Alien Property Custodian, Division of Patent Administration, 'Investigation Report', RG 131 Box 400 VO 5251.

${ }^{62}$ George W. Merck to Karl Merck 30 th January 1922 - 'If we can only get on a profit making basis again', he lamented. EMA A1032.

${ }^{63}$ Karl Merck to George W. Merck, 24th February 1922, EMA A1032. Rahway was also asked to investigate outstanding intellectual property (trademarks and patents) claims in Canada on behalf of Darmstadt.

${ }^{64}$ George W. Merck to Karl Merck, 5 ${ }^{\text {th }}$ April, 1922, EMA A1032. Dr Fritz Merck was the director of E. Merck's laboratories.

${ }^{65}$ Karl Merck to George W. Merck, 24th May, 1922, EMA A1032.

${ }^{66}$ George W. Merck to Karl Merck, 15th December, 1922. 'Rudi Gruber... felt that it would be more profitable for both of us to manufacture the article over here.' EMA E10/ $2674 b$.

${ }^{67}$ George W. Merck to Karl Merck, 14th July, 1922, and Karl Merck to George W. Merck $13^{\text {th }}$ October, 1922, both EMA A1032.

${ }^{68}$ George W Merck to Louis Merck, $7^{\text {th }}$ November, 1924, B/28a; Louis Merck to George W. Merck 14th January, 1925 B/28b; George W. Merck to Louis Merck 4th March, 1925, B/28a; all in EMA.

${ }^{69}$ George W Merck to Karl Merck, $15^{\text {th }}$ June, 1925, 'It is certainly disturbing to have quotations made direct to our customers. It would seem further, that solicitations originated with your firm and this practice, too, is upsetting.' EMA E10/ 2674b.

70 George W Merck to Louis Merck, 23 ${ }^{\text {rd }}$ October, 1925, EMA B/28a. Dr Rudi Gruber was also George W. Merck's brother-in-law and a Merck \& Co. Board Director. Sturchio and Galambos, Values and Visions, p. 177.

71 The six Darmstadt specialties were Methyl p-amidophenol, agreement date November 1921; Veronal, December 1921-January 1922; Thiosamine, February 1922; Phenolphthalein, September to October 1922; Eukodal, February to May 1923; Cuprex, September to October 1925. The subsequent mutual exchange was for the Rahway process for colloidal iodine to be exchanged for Darmstadt's Ephetonin process, both November 17th, 1928. See APC, 'Investigation Report', Exhibit A.

72 Galambos and Sturchio, 'Transnational Investment', pp. 241-2.

73 Galambos and Sturchio, 'Transnational Investment', pp. 241-2; Gortler, 'Merck in America', pp. 2-3; 'Rosengarten interview', p. 2. The Rosengarten family wanted to sell up and were looking for possible partners. They had explored a potential acquisition by 
Pfizer, but this apparently fell foul of anti-trust concerns. Because Merck \& Co. was both so much smaller and were struggling, the newly merged company posed no anti-trust threats and the merger proceeded speedily. The Rosengartens even lent George F. Merck $\$ 5 \mathrm{~m}$ or $\$ 6 \mathrm{~m}$ to complete the takeover.

74 Rosengarten interview, pp. 6-7; Gortler, 'Merck in America', pp. 2-3.

75 Sturchio and Galambos, 'German Connection', p. 12.

76 Table 1 above for comparative employment in the 1930s. Citation from Division of Investigative Research, Aliens Property Custodian, 'Merck \& Co Inc. Rahway NJ.

Memorandum', $28^{\text {th }}$ February 1944, p. 11. RG131/230/38/34/07.

77 George W. Merck to Karl Merck, 11 ${ }^{\text {th }}$ June, 1928, p. 1. EMA E10/ 2674b.

78 George W. Merck to Karl Merck, 11 th June, 1928, p. 3.

79 George W. Merck to Karl Merck, 11 th June, 1928, p. 4.

80 George W. Merck to Karl Merck $25^{\text {th }}$ July 1928, followed by various others - EMA E10/ 2674b.

${ }^{81}$ Kobrak, National Cultures, pp. 159-60.

${ }^{82}$ Schneider, 'Das wissenschaftliche Unternehmen', emphasizes the importance of centralization to the Darmstadt business model in the 1920s. Liebenau, 'Modernizing the Business of Health', outlines how quality control concerns meant centralization of production was the typical strategy for all the larger pharmaceuticals companies in the interwar period.

83 Karl Merck to Louis Merck, 15 ${ }^{\text {th }}$ November, 1931, EMA B/15a.

${ }^{84}$ APC, 'Investigative Report'; OMGGUS 'Report'.

85 Karl Merck to Louis Merck, 15th November, 1931, EMA B/15a, that 'research laboratory work cannot be exchanged at an early stage in both places was fully understood', (authors' translation).

86 Ibid., (authors' translation).

87 Sturchio and Galambos, Values and Visions, p. 27. Rosengarten interview, pp. 5-6.

88 Max Tishler interview with Leon Gortler, MA, p. 4.

${ }^{89}$ Bernschneider-Reif, Was mensch tun kann, p. 95; OMGGUS, pp.??

90 It actually opened in April, 1933, Merck Review, vol. 19 (4), November, 1958 MA.

Lesch, Miracle Drugs, pp. 198-202 on the MITR.

${ }^{91}$ George W. Merck to Louis Merck, $10^{\text {th }}$ February, 1932; 26 ${ }^{\text {th }}$ February 1932; and May $13^{\text {th }}, 1932$; all in EMA B/18c.

${ }^{92}$ Louis Merck to George W. Merck, $4^{\text {th }}$ November, 1932, EMA B/29b, (authors' translation).

93 'Copy E. Merck and Merck \& Co., Inc. Treaty Agreement. Dated November 17th 1932. MA. Wilkins, History of Foreign Investment, n. 315, p. 815, mentions the existence of the Treaty, but does not develop its significance. Galambos and Sturchio, 'Transnational Investment', stops before reaching the events of 1932, although see n. 56, p. 242. On similar general and overarching agreements on technology sharing between US overseas companies, the Du Pont-ICI 1929 Patents and Processes Agreement is perhaps the best known. See Wilkins, History of Foreign Investment, p. 405; and Steen, American Synthetic Organic Chemicals, pp. 242-286.

94 The 'spheres of influence' comment is from OMGGUS, 'Report', p.45.

95 Lukens to George W. Merck, 7th June, 1933, 'Trip to Germany', MA; 'Darmstadt Processes Exchanged', 14th June, 1933, MA; 'Details of Why Processes were Exchanged', 7th July, 1933, MA.

96 'Details of Why Processes were Exchanged'. There were no further explanatory notes.

97 Lukens, 'Trip to Germany'. 
98 George W. Merck to Karl Merck, 12th December, 1933, MA.

${ }^{99}$ George W. Merck to Karl Merck, 24th March, 1934, MA.

100 At least 38 of the U.S. patents assigned to Merck \& Co. from 1932 to 1940 were based on E. Merck technology, letter from Reverdy Johnson to Richard W. Hogue Jr., of Hughes, Hubbard \& Ewing (Merck \& Co.'s Wall Street lawyers), October 24th, 1944, copy at MA. Table 1 above for Merck \& Co patents for 1937-1939.

${ }^{101}$ Lesch covers the Institute in, Miracle Drugs, pp. 198-9. In order to gain a license for animal experimentation under New Jersey anti-vivisection law, the state required the Institute to be legally separate from the company. This has led some to assume that this was the driver of the Institute's creation. However Rosengarten emphasises that this was an afterthought - see Interview, pp. 9-10. Hans Molitor came from Vienna because there was no American university scientist of sufficient standing willing to leave academia, Rosengarten interview, p. 8. The opening of the Merck Institute was followed by Lilly's Research Laboratories (opened 1934), then Abbott and Squibb opening their own research centers in 1938. Abbott invested $\$ 1 / 2 \mathrm{~m}$ in its 1938 Research Centre, Abbott Almanac, p. 10. Swann views these as particularly significant moments in the development of the U.S. industry, Swann, Academic Scientists, pp. 41-47. However, as with any image building exercise, it was easy for the currency to become debased. In 1937 Warner opened up is own research institute to great fanfare, and Warner never had any research pretensions. Deeson, Parke, Davis, p. 42.

102 Tishler interview, pp. 4-5. Lesch describes Tishler as 'among the most articulate of commentators' on the development of pharmaceutical research in the US from the 1930 s to the 1960s, in Miracle Drugs p. 6.

103 Lesch, Miracle Drugs, pp. 198-9; Swann, Academic Scientists, pp. 46-48.

${ }^{104}$ Research expenditures, see above. Sturchio and Galambos, 'As late as 1933 very little research was done at Merck. What little was done, was focused on process development', Values and Visions, p. 68.

105 Tishler was recruited from Harvard in 1937 attracted to Merck because of the work done by Cline and Williams on isolating and manufacturing Vitamin B1. Tishler interview, pp. 4-5; Sturchio and Galambos, Values and Visions, p. 70. Jack Connor reckoned that Merck \& Co's critical intervention to gain research capabilities was the establishment of a war-time committee to recruit research talent; Connor interview, p. 19 [Connor was Merck \& Co.'s senior counsel, and then President from 1955 to 1965]. 106 Swann, Academic Scientists, pp. 47-8.

107 In 1954 Merck \& Co. produced the fifth largest number of research publications (90) in the U.S. (after GE, Bell Telephone, Du Pont and American Cyanamid). Fisher, Science 1959, Table 1, p. 1654, also cited by Swann, n.55, p. 191. In 1932, by contrast, Merck's entire scientific publication output summed to just two papers. In 1935 there were ten, rising to 18 in 1938. Moreover, these were almost all in chemicals journals. Merck's first paper to be published in the area of physiology or pharmaceuticals appeared only in 1935. Pharmaceuticals papers only attained any relative significance from 1938 or 1939, when 18 and 36 papers were published in total, of which 8 and 14 were in pharmaceutical journals. MA. Swann, Academic Scientists, p. 47, says that the Institute's scientists published over thirty papers in its first five years. Merck \& Co.'s total output of papers from 1933 to 1937 (inclusive) was 47 publications, suggesting that scientific publications from Merck's non-Institute scientists remained at the moribund level of around three per year.

108 Rosengarten interview, p. 10.

109 Copies in the US National Archives, MA and EMA. 
110 The Research Protocol lists the following Darmstadt developments, improved ether (anaesthetic), quinine, and proccaine (alkaloids and anti-spasmotics), spasmolytics (anti-spasmotic), ergotin, (vagomimetic) digitoxin and ephedrine (sympathomimetic alkaloids), and Vitamin C. Merck \& Co's products included papaverin, colloidal iodine solution, sodium perborate, acetyl salicylic acid, all fine chemicals, and vinethine and vitamin B1 as their two specialties, both of which originated from outside inventors. The inventor of synthetic Vitamin B1, R. R. Williams, was an employee of Bell Telephone. Vinethine (divinyl ether) was invented by Dr Irving Bell, of the University of Alberta. Finucane, 'Canadian contributions'.

${ }^{111}$ George W. Merck to Karl Merck, 25 th October, 1933, EMA, A1032.

112 The Institute conducted experimental research for university researchers, for example. Swann, Academic Scientists, pp. 47-8.

113 'Draft reply to U.S. Department of Justice in the anti-trust suit against Merck \& Co., January $28^{\text {th }} 1944^{\prime}$, MA. This source documents almost all visits between the two companies from 1914 to 1942 , with a summary description of their purposes. After eight successive years (1920 to 1927) when there had been just one visit to Darmstadt per annum, there were two in 1928, three in 1929 (along with a return visit from Darmstadt to Rahway), rising to four in 1931. George W. Merck to Louis Merck, $3^{\text {rd }}$ August, 1936, glad that Koll and Dalmer are coming to Rahway and that Engels and Molitor to visit Darmstadt, B/18c; Dr Siebert of Darmstadt to visit Major and Molitor at Rahway, George W. Merck to Louis Merck, 12 th February, 1935 B/18c; and Louis Merck to Gruber 9th May, 1935 discussions with Scientific department all questions to be answered, Dr Dalmer will write, B/18b. Gruber to Louis Merck 'Darmstadt visit gave lots of stimulation' 28 ${ }^{\text {th }}$ July, 1936 B/18b, (author's translation). All at EMA. 114 George W. Merck to Louis Merck 12 th February, 1935 B/18c; 'Cebion Agreement, November 17th, 1936', E. Merck to Merck \& Co., 25th November, 1936, MA. 115 'Verfahrenes...' 24th October, 1937, MA.

116 Treaty Agreement, revised, $10^{\text {th }}$ June 1938, MA.

117 Merck Review, November 1958, pp. 5-6.

118 APC Division of Investigative Research, 'Merck \& Co', the vitamin business became significant for the business, 'after 1939', p. 19. 'Prospectus, December 9th 1941', RG131. 119 There is an enormous volume of correspondence on this at Darmstadt, see EMA S4/87b and S4/87c.The first mention in the correspondence is in May 1935 when Louis Merck writes to Gruber that he had forwarded Rahway's information to Darmstadt's scientists, which had prompted a lot of questions - partly because they were aware that IG Farben had lodged a potentially competing patent. Louis Merck to Gruber, $9^{\text {th }}$ May, 1935 B/18b; Louis Merck to Gruber, 28 ${ }^{\text {th }}$ July, 1936, B/18b; George W. Merck to Louis Merck, $3^{\text {rd }}$ August, 1936 (Dalmer coming to discuss Vitamin B1 situation), B/18c, all EMA.

120 Gruber to Audit Department, 'E. Merck joint account Cebione-Ascorbic Acid', 3 ${ }^{\text {rd }}$ January, 1939, MA.

${ }^{121}$ It wasn't true. But it triggered the first of a series of wartime investigations.

'Specialist Unit A Files: Merck \& Co. Inc,' 17th February, 1942, Foreign Funds Control Docket Files, 1940-1960, Box 11, 'Merck' folder, RG131/230/38/34/07. On the new version of the Alien Property Custodian that was formed in the second world war, see White, 'Alien Property Custodian'.

122 Perkin to Blauvelt letter 1942.

123 OMGGUS, 'Report', on the importance of how to interpret the Treaty, for instance. 124 Galambos and Sturchio, 'Transnational Investment', pp. 241-2. 
125 Sturchio and Galambos, 'German Connection', p. 14.

${ }^{126}$ Sturchio and Galambos, 'German Connection'. Lynn, Billion Dollar; Mahoney, Merchants; Sturchio and Galambos, Values and Visions; Galambos and Sewell, Networks; Galambos and Sturchio, 'Sustaining Innovation'. George W Merck was designated special confidential assistant to both President Roosevelt and the Secretary of War. He was rewarded with the Award of Merit, then the equivalent of the Congressional medal. 127 Sturchio and Galambos, 'German Connection'.

${ }^{128}$ Steen, American Synthetic Organic Chemicals, p. 291. 